University of California, Hastings College of the Law

UC Hastings Scholarship Repository

Faculty Scholarship

2019

\title{
Coupling Labor Codes of Conduct and Supplier Labor Practices: The Role of Internal Structural Conditions
}

Jodi L. Short

UC Hastings College of the Law, shortj@uchastings.edu

Michael W. Toffel

Yanhua Bird

Follow this and additional works at: https://repository.uchastings.edu/faculty_scholarship

\section{Recommended Citation}

Jodi L. Short, Michael W. Toffel, and Yanhua Bird, Coupling Labor Codes of Conduct and Supplier Labor Practices: The Role of Internal Structural Conditions, 30 Org. Sci 647 (2019).

Available at: https://repository.uchastings.edu/faculty_scholarship/1752

This Article is brought to you for free and open access by UC Hastings Scholarship Repository. It has been accepted for inclusion in Faculty Scholarship by an authorized administrator of UC Hastings Scholarship Repository. For more information, please contact wangangela@uchastings.edu. 


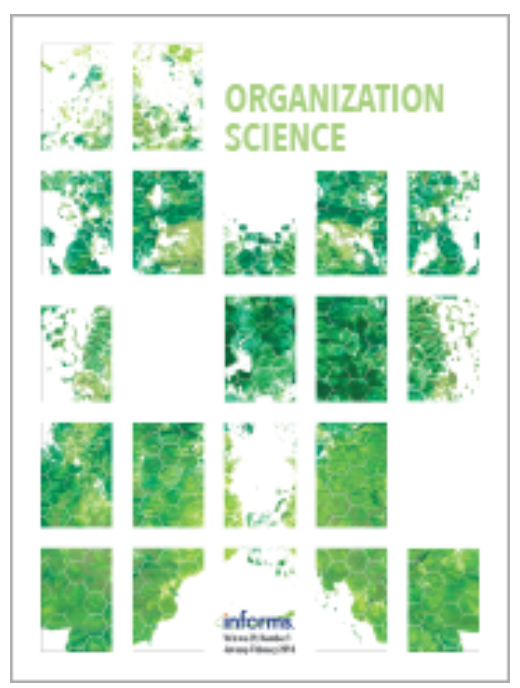

\section{Organization Science}

Publication details, including instructions for authors and subscription information: http:// pubsonline.informs.org

\section{Coupling Labor Codes of Conduct and Supplier Labor Practices: The Role of Internal Structural Conditions}

Yanhua Bird, J odi L. Short, Michael W. Toffel

\section{To cite this article:}

Yanhua Bird, J odi L. Short, Michael W. Toffel (2019) Coupling Labor Codes of Conduct and Supplier Labor Practices: The Role of Internal Structural Conditions. Organization Science

Published online in Articles in Advance 30 Apr 2019

. https:// doi.org/ 10.1287/ orsc. 2018.1261

\section{Full terms and conditions of use: https://pubsonline.informs.org/page/terms-and-conditions}

This article may be used only for the purposes of research, teaching, and/or private study. Commercial use or systematic downloading (by robots or other automatic processes) is prohibited without explicit Publisher approval, unless otherwise noted. For more information, contact permissions@informs.org.

The Publisher does not warrant or guarantee the article's accuracy, completeness, merchantability, fitness for a particular purpose, or non-infringement. Descriptions of, or references to, products or publications, or inclusion of an advertisement in this article, neither constitutes nor implies a guarantee, endorsement, or support of claims made of that product, publication, or service.

Copyright (c) 2019, INFORMS

Please scroll down for article-it is on subsequent pages

INFORMS is the largest professional society in the world for professionals in the fields of operations research, management science, and analytics.

For more information on INFORMS, its publications, membership, or meetings visit http:// www. informs. org 


\title{
Coupling Labor Codes of Conduct and Supplier Labor Practices: The Role of Internal Structural Conditions
}

\author{
Yanhua Bird, ${ }^{a}$ Jodi L. Short, ${ }^{b}$ Michael W. Toffel ${ }^{a}$ \\ ${ }^{\mathbf{a}}$ Harvard Business School, Boston, Massachusetts 02163; ${ }^{\mathbf{b}}$ University of California, Hastings College of the Law, San Francisco, \\ California 94102 \\ Contact: ybird@hbs.edu, (D) http://orcid.org/0000-0002-8164-6422 (YB); shortj@uchastings.edu, (DD http://orcid.org/0000-0002-0061-1966 (JLS); \\ mtoffel@hbs.edu, (D) http://orcid.org/0000-0002-1224-9159 (MWT)
}

Received: July 9, 2017

Revised: April 11, 2018; July 30, 2018;

August 30, 2018

Accepted: September 6, 2018

Published Online in Articles in Advance: April 30, 2019

https://doi.org/10.1287/orsc.2018.1261

Copyright: ๑) 2019 INFORMS

\begin{abstract}
In response to media exposés and activist group pressure to eliminate exploitive working conditions, multinational companies have pushed their suppliers to adopt labor codes of conduct and improve their labor practices to meet the standards set forth in these codes. Yet little is known about the extent to which suppliers are improving their labor practices to conform to codes of conduct, especially in organizations in which legitimacy structures like codes compete with productivity-driving incentive structures. We theorize that the presence of particular internal structures will affect the extent to which suppliers' labor practices will become more tightly aligned-or coupled-with their formal commitments to adhere to labor codes. Specifically, we theorize high-powered productivity incentives to be associated with less coupling, and being certified to management system standards and having workers' unions to be associated with more coupling. We also argue that these efficiency and managerial structures will moderate each other's relationship to coupling, and that certification and unions will each increase the other's positive association with coupling. Using social audit data on 3,276 suppliers in 55 countries, we find evidence that supports our hypotheses. Our focus on the internal structural composition of suppliers extends the decoupling literature by theorizing and demonstrating conditions under which suppliers' core organizational functions are likely to be buffered from change by legitimacy structures. Furthermore, our findings suggest important strategic considerations for managers selecting supplier factories and provide key insights for the design of transnational sustainability governance regimes.
\end{abstract}

Funding: Financial support came from the Division of Research and Faculty Development, Harvard Business School.

Supplemental Material: The online appendix is available at https://doi.org/10.1287/orsc.2018.1261.

Keywords: decoupling • organizational structures • labor standards • global supply chain

Suppliers to global value chains face multiple, intense, and conflicting pressures from their institutional environment. Foremost are the formidable efficiency demands of the global value chain to produce ever more cheaply and rapidly (Bartley 2005, Gereffi 2005). The productcost economics of global production have pushed lowvalue-added segments of generic services and volume production to suppliers in the Global South, which compete principally on labor costs and operate with very low margins (Gereffi and Christian 2009). Global buyers' demanding sourcing practices magnify these efficiency pressures (Anner et al. 2013, Locke 2013). Meeting efficiency demands is the core organizational imperative of global suppliers, and they structure their organizations accordingly, resulting in a "race to the bottom" in labor practices (Bartley 2005, Gereffi 2005), commonly resulting in sweatshop conditions (Anner et al. 2013).

Suppliers also face increasingly forceful and potentially contradictory legitimacy demands to improve workplace conditions. These demands come primarily from multinational buyers that are, themselves, subject to myriad institutional pressures to raise labor standards in their supply chains (Okhmatovskiy and David 2011, Distelhorst et al. 2016). High-profile catastrophes like the Rana Plaza building collapse that killed more than 1,000 factory workers in Bangladesh have attracted worldwide attention to hazardous supply chain working conditions, spawning private political activism and increasing reputational pressure on global brands to improve them (Bartley and Child 2014). Shareholder resolutions demanding supply chain due diligence and observance of international human rights norms are commanding higher levels of support each proxy season. Increasingly, MNCs face domestic and international legal obligations to monitor and report on conditions in their supply chains and to adhere to the voluntary commitments they make to improve supply chain working conditions.

MNCs have responded to these legitimacy pressures, in large part, by pressuring their suppliers to adopt 
organizational structures, policies, and procedures to improve working conditions. The most common of these are labor codes of conduct and monitoring programs. Codes of conduct are contractual provisions drafted by buyers that set forth standards governing working conditions like wages, hours, child labor, discrimination, and occupational health and safety (Locke 2013). Codes typically are based on the core labor standards articulated by the International Labor Organization, and buyers require suppliers to agree to adhere to them as a condition of doing business. Monitoring programs deploy private social auditors to inspect suppliers and assess their adherence to codes of conduct. Social auditing of suppliers is pervasive, with hundreds of thousands of audits conducted on behalf of individual firms and multi-stakeholder initiatives each year (Gould 2005), driving an $\$ 80$ billion social auditing industry (AFL-CIO 2013).

Although suppliers adopt buyers' codes of conduct as a condition of doing business, codes are unlike core contractual terms like price, quantity, and quality in that codes seek to satisfy institutional legitimacy demands rather than to promote transactional efficiency. Brands impose codes to protect their reputations and preserve their legitimacy, not to improve productive efficiency (Lamin and Zaheer 2012, Locke 2013). While brands seek the reputational cover that codes provide, their behavior betrays ambivalence about whether they want suppliers to rigorously implement code provisions. For instance, although codes of conduct require suppliers to observe maximum hours limitations, many buyers continue to make sourcing demands that are nearly impossible to meet without excessive overtime (Locke 2013). Similarly, although codes require compliance with minimum wage standards, brands continue to squeeze suppliers on margins, eroding their ability to pay minimum wages (Locke 2013). Perhaps most tellingly, the requirements of codes of conduct are rarely enforced by the brands that impose them. While violations of the code constitute a contractual breach that would justify terminating the business relationship, buyers rarely exercise this power (Locke 2013, Bader 2015, Starmanns 2017). As Locke (2013, p. 32) observed, "It is an open secret that few brands ever exit factories, even when they are found not to be in compliance with the codes of conduct and that most compliance officers have less influence than their purchasing or sourcing colleagues when deciding whether to place (or continue) an order with a noncompliant factory."

Buyer ambivalence about codes of conduct raises the possibility that suppliers may decouple these formal policies from their labor practices to meet efficiency demands. Decoupling can occur on two dimensions. First, legitimacy structures like codes might be decoupled from organizational practices altogether, meaning that "they are unimplemented or routinely violated"
(Bromley and Powell 2012, p. 489). This is the traditional conception of decoupling, in which organizations adopt structures symbolically to shield their internal practices from outside scrutiny and gain legitimacy with external stakeholders without disrupting the pursuit of internal, organizational imperatives (Thompson 1967, Meyer and Rowan 1977, Pfeffer and Salancik 1978). Second, decoupling can occur when legitimacy structures are largely implemented within an organization despite a lack of a clear integration with that organization's core goals. Under these circumstances, the organizational core may be internally buffered from influence by seemingly incompatible legitimacy structures (Bromley and Powell 2012). This conception of decoupling has developed more recently to accommodate the insight that it is increasingly difficult to completely decouple policy from practice in highly rationalized institutional environments, and yet some organizational structures nonetheless fail to meaningfully impact core organizational activities because they are marginalized internally.

While these two dimensions of decoupling have been elaborated theoretically, existing empirical studies have focused largely on the first. Many studies address the coupling and decoupling of organizational structures and practices, but there is a "general dearth of research on buffering between internal practices" (Bromley and Powell 2012, p. 499). We extend this literature by investigating how different configurations of internal organizational structures are related to the buffering of legitimacy structures (i.e., labor codes) to protect the organizational core. Specifically, we investigate the internal structural conditions under which suppliers' labor practices are likely to be more tightly aligned-or coupled - with the formal commitments they have made to adhere to labor codes of conduct. Our focus on internal structural conditions acknowledges that legitimacy structures like codes of conduct do not exist in a vacuum; they coexist with an elaborate ecosystem of organizational structures adopted by suppliers to meet the competing demands of their institutional environments (Meyer and Rowan 1977; Bromley and Powell 2012). For instance, many suppliers adopt "efficiency structures" in the form of incentives to spur productivity and meet efficiency demands. Suppliers might also adopt "managerial structures" like certified management systems to meet market demands for operational resilience and consistency or institutional demands for environmental sustainability or observance of human rights. Institutional pressures have led some suppliers to institute managerial structures that provide formal channels for worker participation, such as unions and joint planning procedures. We investigate the association between such organizational structures and the extent to which suppliers couple their labor practices with the standards contained in codes of conduct. We highlight that some organizational structures can act as a buffer-a 
protective barrier that shields core production activities from potentially threatening changes by legitimacy structures-while other organizational structures are associated with less buffering and thus tighter coupling of legitimacy structures and organizational practices.

We examine these relationships on a proprietary data set obtained from a large social auditing firm that contains 8,323 audits of 3,276 suppliers in 55 countries conducted between 2012 and 2015. All of these suppliers have adopted labor codes of conduct and are subject to routine auditing, but they differ in their adoption of other types of organizational structures to advance efficiency and other managerial goals. We find that suppliers with high-powered incentive structures lag in improving labor practices and adhering to codes of conduct, suggesting that these structures act as a buffer to protect core production activities in factories that are highly motivated by efficiency imperatives. In contrast, we find tighter coupling of codes and practices at suppliers that adopt certified management systems and unions, managerial structures that provide mechanisms for dialogue across the organization that make it more difficult to isolate legitimacy structures (such as codes) from production activities (such as labor practices). Furthermore, we find important interactions between these internal structures. On the one hand, we demonstrate that managerial structures attenuate the negative association between efficiency structures and improvement. On the other hand, we find that the converse is also true: efficiency structures attenuate the positive relationship between legitimacy structures and improvement. Finally, the presence in one supplier of multiple managerial structures-in our study, unions and certificationhastens improvement, suggesting that they are complements and not substitutes.

Our focus on the internal structural composition of organizations is an important contribution to the decoupling literature. First, it moves beyond the traditional focus on the coupling effects of external institutional factors. This is a particularly important extension, because many suppliers operate in institutional environments that lack significant pressure to comply with labor standards (James et al. 2018). We build on a handful of studies that qualitatively investigate intraorganizational processes of coupling and decoupling (Boiral 2007, Hallett 2010, Overdevest 2010, Tilcsik 2010, Bartley and Egels-Zandén 2016). Second, we also extend the decoupling literature by examining how multiple and potentially conflicting organizational structures are related to the coupling of legitimacy structures and organizational practices. Our approach allows us to elaborate the underdeveloped theoretical concept of internal buffering to encompass the interaction of legitimacy structures and other organizational structures rather than their mutual isolation. This innovation is crucial to understanding coupling processes in a world in which organizations are subject to complex demands that they often address by adopting multiple and competing formal organizational structures. Third, our investigation of the organizational incentive structures that operationalize environmental efficiency demands is a novel and important attempt to address the relationship between legitimacy and efficiency imperatives that lies at the core of the decoupling literature. Conventionally, efficiency demands are assumed to be a given condition of the environment in which business firms operate. Our study investigates how these organizations operationalize efficiency demands as incentive structures and how these structures can act as a buffer protecting the core productive activities of the firm from legitimacy structures perceived to threaten them.

\section{Coupling Legitimacy Structures and Organizational Practices}

The existing literature describes two ways that legitimacy structures can be decoupled from organizational practices. First, legitimacy structures can be adopted symbolically to appease external stakeholders (Thompson 1967, Meyer and Rowan 1977, Pfeffer and Salancik 1978) while remaining "unimplemented or routinely violated" (Bromley and Powell 2012, p. 489). In our context, this would mean that suppliers agree to codeof-conduct requirements requested by buyers but do not take concrete steps to implement them. The bulk of theoretical and empirical research on decoupling, particularly those studies focused on legal compliance (Sutton and Dobbin 1996, Short and Toffel 2010), addresses this type of "policy-practice" decoupling. Insights from this literature suggest that legitimacy structures adopted by suppliers are likely to be decoupled from their practices for three principal reasons. First, organizational structures adopted in response to legitimacy demands tend to be implemented symbolically and decoupled from organizational practices that advance the technical or efficiency-related demands of production work (Meyer and Rowan 1977, Bromley and Powell 2012). Second, decoupling is particularly likely in less-elaborated institutional environments, where efficiency demands are strong and institutional pressures to implement legitimacy structures are weak (Meyer and Rowan 1977), as they are in the emerging economies in which many suppliers are located. Third, the implementation of legitimacy-related structures requires organizational resources that many suppliers operating on extremely tight margins lack (Bromley and Powell 2012, Lim and Tsutsui 2012).

Consistent with these general propositions, the bulk of studies finding coupling between legitimacy structures and organizational compliance with legitimacy demands have attributed it to coercive institutional pressures like state power and civil society political mobilization (Dobbin and Kelly 2007, Seidman 2007, 
Short and Toffel 2010, Lim and Tsutsui 2012, Toffel et al. 2015). For instance, studies of suppliers' compliance with labor standards have focused on the coupling effect of pressures from the institutional environment, including consumer pressure (O’Rourke 2003, Gereffi 2005, Vogel 2008, Toffel et al. 2015); pressure from civil society actors like activists, nongovernmental organizations (NGOs), and the press (Seidman 2007, Vogel 2008, Anner 2012, Anner et al. 2013, Distelhorst et al. 2015, Toffel et al. 2015, Bartley and Egels-Zandén 2016, James et al. 2018); and pressures from the state (Bartley 2011, Distelhorst et al. 2015, Toffel et al. 2015, Amengual and Chirot 2016). While this prevailing theoretical framework contains important and cautionary lessons about the acute threat of decoupling in less-elaborated institutional environments, it provides little insight into when coupling is possible and how it might vary across firms operating in these environments.

A second, alternative conception of decoupling has emerged in the institutional literature based on the observation that the type of "policy-practice" decoupling described above may not be as rampant as traditionally predicted. Bromley and Powell (2012) argue that in highly rationalized institutional environments, legitimacy structures are likely to be at least somewhat coupled with organizational practices. This is because it is very difficult to divorce formal policy from on-theground practice completely "in an increasingly managerial world that emphasizes evaluation, standardization, and benchmarking" (Bromley and Powell 2012, p. 485). In highly rationalized environments, legitimacy structures are likely to "have real organizational consequences" (Bromley and Powell 2012, p. 496) in the sense that staff and resources are devoted to their operation. However, those consequences may not extend to mitigating the harms that prompted the adoption of the legitimacy structure. Even if environmental rationalization promotes concrete implementation of legitimacy structures, those structures may nonetheless be prevented from fundamentally changing practices that are central to the organization's core mission. The organizational core will be "internally buffered" (Bromley and Powell 2012), or protected, from the impact of legitimacy structures that are at odds with it. The existing literature argues that internal buffering is accomplished by isolating the technical core of the organization from potentially threatening organizational structures (Binder 2007, Bromley and Powell 2012).

These insights suggest that codes of conduct will be implemented to some degree rather than entirely decoupled from supplier practices, because global value chains are highly rationalized institutional environments. Organizations comprising global value chains furnish rules of conduct and continuously monitor compliance through routine monitoring by buyers and social auditors. Organizations in the global institutional environment, including NGOs, activists, governments, and intergovernmental organizations, likewise have embraced managerial tools like codes and monitoring to improve labor conditions in global supply chains (Utting 2005, Nolan 2014, LeBaron and Lister 2015). This is precisely the type of hyper-rationalized environment in which complete decoupling of policy from practice may be untenable. In fact, numerous studies document that audited factories tend to improve compliance with labor standards on average over time as measured by audit scores (Locke et al. 2007, Shea et al. 2010, Nadvi et al. 2011, Ang et al. 2012, Locke et al. 2013, Toffel et al. 2015).

Yet, codes may nonetheless fail to improve supplier labor practices if they are internally buffered by other organizational structures to protect core productive activities. Neither existing research on decoupling nor the rationalization thesis explain why some suppliers improve more than others under similar institutional conditions. This suggests the need to investigate the internal composition of supplier organizations to identify structural conditions under which supplier labor practices are internally buffered from the potentially threatening changes demanded by codes of conduct. Specifically, we investigate the extent to which core production activities like labor practices are internally buffered from improvement in labor practices to better adhere to labor codes under different constellations of internal organizational structures. Further, we challenge the prevailing view in the literature of buffering as the isolation of some organizational structures from others and investigate interactions between different structures and their relationship to coupling outcomes. In so doing, our study provides critical empirical insights and theoretical tools to explain variation in the coupling of organizational legitimacy structures in the absence of commonly studied external pressures such as strong state regulation and robust civil society.

We define legitimacy structures as being more tightly coupled when they are associated with changes in organizational practices that more closely align practices with institutional demands. In our context, that means improvement in compliance with codes of labor conduct. We provide this definition at the outset, because the existing literature has been vague in defining coupling. Many claim to identify coupling or decoupling outcomes at a static point in time and do not examine relationships between organizational structure and organizational change (e.g., Westphal and Zajac 2001, Zajac and Westphal 2004, Lim and Tsutsui 2012). While coupling may mean different things in different contexts, we contend that organizational change is the touchstone for identifying coupling between legitimacy structures and compliance with normatively based institutional legitimacy demands, because such demands are typically made to spur improvements in organizational behavior that falls short of some normative ideal. 


\section{Organizational Structures and the Coupling of Codes with Practices}

Below, we theorize that the degree to which suppliers couple their labor practices with legitimacy structures like codes of conduct is related to the presence of other structures in these organizations. Specifically, we consider one efficiency-driving structure (high-powered productivity incentives) and two managerial structures (certified management systems and unions). We argue that codes will be less tightly coupled with labor practices when they compete with high-powered productivity incentive structures; in such a circumstance, these efficiency structures will act as a buffer between core production activities and the intrusive changes code adherence would require. Such buffering will inhibit the improvement of labor practices to adhere to labor codes. Conversely, codes and practices will be more tightly coupled, and buffering will be less pronounced, in suppliers with managerial structures oriented toward improving organizational processes and fostering dialogue across the organization (that is, certified management systems and unions), because the presence of such managerial structures makes it more difficult to isolate legitimacy structures (such as codes) from production activities (such as labor practices). We also investigate how the interaction between managerial structures and efficiency structures relates to the coupling of codes and labor practices. We argue that, on one hand, managerial structures that can help organizations reconcile legitimacy and efficiency imperatives will attenuate the negative relationship between efficiency structures and code and practice coupling. On the other hand, efficiency structures attenuate the positive relationship between managerial structures and coupling. Finally, we hypothesize that the two managerial structures we study, certified management systems and unions, complement one another by providing, respectively, diverse channels for cross-organizational communications and inputs from multiple parties in that dialogue. We illustrate our theoretical framework in Figure 1.

While we hypothesize associations between (and among) various internal organizational structures and the extent to which legitimacy structures will be coupled with organizational practices, we do not make any claims about the causal mechanisms driving these relationships. For example, internal organizational structures such as the managerial structures we examine might provide mechanisms that drive changes in organizational practices, or organizations might be more likely to adopt such structures if they already have the will and capacity to achieve the changes sought by external stakeholders. Our data do not allow us to discern with confidence whether such structures are signals or mechanisms of organizational improvement. It is an important first step to identify organizational structural conditions under which code compliance is likely to improve, regardless of the causal mechanisms, because these conditions provide a useful set of decision heuristics for reputation-conscious brand managers selecting which suppliers to work with and for regulators and activists selecting which suppliers to target for monitoring and enforcement.

\section{Efficiency Structures and Code Coupling}

The economics of outsourced transactions create a buyerdriven global supply chain characterized by razor-thin pricing margins and buyers' volatile and time-sensitive ordering practices (Gereffi 2005). These efficiency imperatives exist not only in suppliers' institutional environments; they are also baked into the organizational structure of many suppliers in the form of productivity incentives. In response to the global value chain's intense efficiency demands, some suppliers adopt incentive structures, ranging from cash bonuses to gift prizes, to promote low-cost, high-volume production (Bartley 2005, Gereffi 2005, Anner et al. 2013, Locke et al. 2013). Some

Figure 1. The Role of Internal Structural Conditions in the Coupling of Labor Codes and Practices

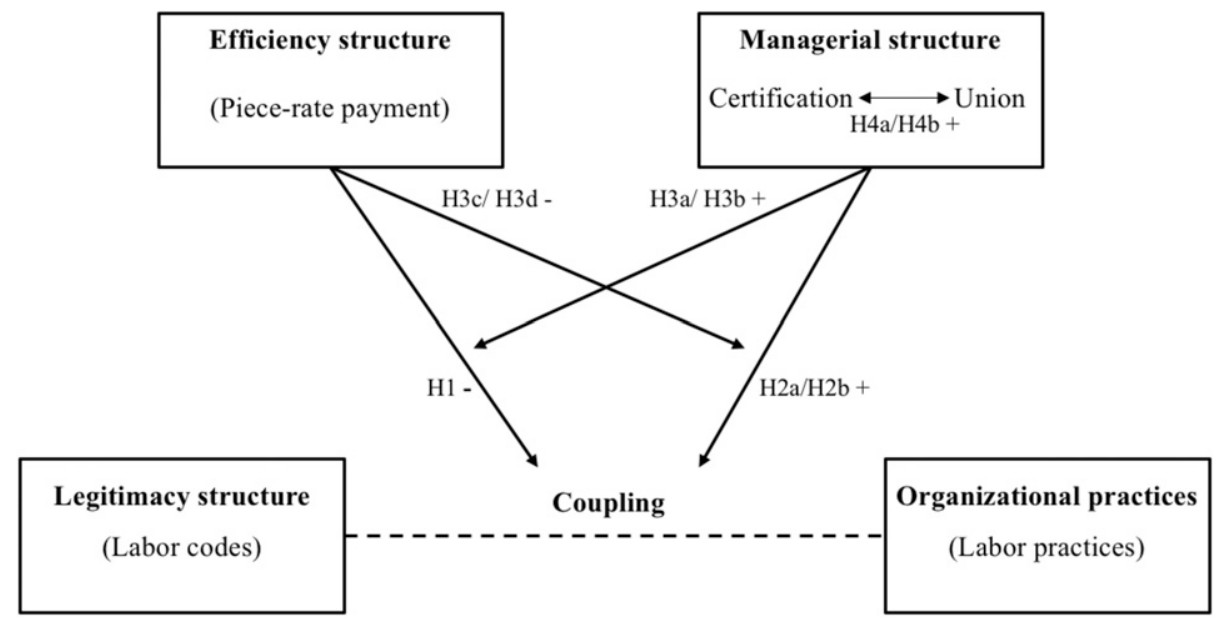


rely on high-powered incentives like piece-rate (or piecework) payment, compensating workers for each unit produced. This incentive structure aims to align workers' incentives with the employer's by giving workers a direct, financial benefit for each incremental improvement in productivity (Williamson 1985, Lazear 2000).

When multiple organizational structures reflecting different logics coexist within an organization, the structure closest to the organization's core tasks and operations is likely to dominate other structures, potentially undermining the aims of the more peripheral structures (Thornton et al. 2012, Besharov and Smith 2014). In the supply chain context, labor codes of conduct are likely to be seen not merely as peripheral, but as potentially incompatible with core organizational productivity imperatives and production activities. The core imperative of suppliers to global value chains is efficient production. Traditionally, suppliers try to meet efficiency demands by cutting labor costs, but policies like codes of conduct that demand adherence to specified labor standards directly threaten this source of competitive advantage. Core production activities are therefore likely to be buffered from codes of conduct that demand changes in labor practices.

High-powered productivity incentives act as a buffer against such changes by structuring the actions of both managers and workers in ways that are likely to protect labor productivity at the expense of improved labor practices. Suppliers that use high-powered productivity incentives tend to be particularly devoted to meeting high, short-term productivity goals (Holmstrom and Milgrom 1991, Prendergast 1999, Dohmen and Falk 2011) and are therefore likely to focus on maintaining or enhancing worker productivity rather than on mitigating the negative social effects of production on workers. Specifically, managers at piece-rate suppliers are unlikely to invest substantial resources to improve labor practices if these investments conflict with shortterm productivity goals. In addition, workers at piecerate suppliers may be more reluctant to adopt operational practices that would improve compliance with labor standards but reduce productivity. For instance, some health and safety procedures-such as wearing personal protection equipment (e.g., masks and steelmesh gloves), participating in emergency training, and using machine guards - can slow the pace of work. Ethnographic research on logging workers shows that piece-rate workers refuse to accept the small but certain economic loss caused by adhering to health and safety procedures but will accept what they perceive as the low probability of being injured on the job, even though that could trigger substantial income loss (Patterson 2007). Research also shows that piece-rate workers are more reluctant to take breaks (Lilley et al. 2002), which may make them more susceptible to mistakes and injuries, and may, in itself, violate some labor codes of conduct.
Just as incentives to cut corners to produce more quickly are associated with inferior labor practices, they are also likely to hinder workers' engagement in practices that would improve those conditions. We therefore hypothesize the following:

Hypothesis 1. Labor codes of conduct will be less tightly coupled to labor practices in suppliers with high-powered productivity incentive structures than in other suppliers.

\section{Managerial Structures and Code Coupling}

Although efficiency structures are likely to act as a buffer between labor codes of conduct and improvements in labor practices, the presence of other types of managerial structure might strengthen that relationship or might signal that the supplier has reasonably tightly coupled its practices to codes. Specifically, we posit that there will be less internal buffering (and more coupling) of legitimacy structures in organizations with managerial structures that bridge the gap between production activities and other organizational activities perceived to threaten them. Below, we examine two of the most commonly advocated and adopted managerial structures in the global supply chain: certification to management systems and unions. We focus on the practices associated with these structures; specifically, suppliers' development of organizational processes designed to facilitate intraorganizational dialogue.

Certified Management Systems. A management system is "the way in which an organization manages the inter-related parts of its business in order to achieve its objectives."1 Many standard-setting organizations supply standards to help firms develop management systems to achieve particular objectives such as quality control (e.g., ISO 9001), environmental management (e.g., ISO 14001), food safety (e.g., HACCP), and labor standards management (e.g., SA8000, ISO 26000). Firms that implement a management system standard can seek certification from a third-party auditor attesting that they adhere. Studies have reached conflicting conclusions about the credibility of certification as a signal of superior practices (e.g., Vinodkumar and Bhasi 2011) and the efficacy of management systems in improving labor practices (e.g., Seidman 2007, Lo et al. 2014).

We investigate a different question: whether certified management systems are associated with tighter coupling between labor codes of conduct and supplier labor practices. We argue that they will be, because they foster the development of organizational processes that promote dialogue across different units of the organization, making it more difficult to isolate organizational activities from one another. As such, they can mitigate the buffering of legitimacy structures to protect efficiency imperatives. Intraorganizational communication processes focusing on internal audits, review meetings, and implementation of corrective actions involving multiple units are at the 
heart of most certified management system standards. For instance, a leading standard focused on process quality requires firms to "continually improve ... through the use of ... audit results, analysis of data, corrective and preventive action and management review" (International Organization for Standardization 2000, p. 13). Similarly, a leading standard focusing on labor practices in global supply chains requires companies to "conduct routine internal audits," "hold periodic meetings to review progress and identify potential actions to strengthen implementation," and ensure that "corrective and preventive actions ... are effectively implemented" (Social Accountability International 2016, p. 126).

These procedures require dynamic input from multiple units, connecting organizational actors from top management to frontline production, logistics, and backoffice operations. Facilitating communication across different units of the organization has the potential to mitigate internal buffering of certain structures by making it more difficult to isolate organizational activities from one another. For example, internal audits and review meetings led by management can reveal flawed core production processes, such as the inappropriate labeling and storage of hazardous chemicals or semifinished products. The implementation of corrective actions such as the institution of proper procedures and employee training to label and store goods involves multiple units including frontline production, logistics, and human resources. These processes thus enhance interunit dialogues, which can reduce the isolation of core production procedures from labor codes of conduct and mitigate workplace injury risks. Thus, we hypothesize the following:

Hypothesis 2a. Labor codes of conduct will be more tightly coupled to labor practices in suppliers certified to management system standards than in noncertified suppliers.

Worker Participation Structures. Contemporary Western management theories emphasize the significance of participatory management and employee empowerment in managing large bureaucratic organizations (Drucker 1974, Wagner 1994, Collins 1997). Distinct from traditional top-down management approaches, participatory management aims to balance the involvement of managers and workers in decision making or problem solving. Instituting worker participation channels such as communication platforms and employee hotlines has become a hallmark of rationalized Western management best practices (Drucker 1974, Wagner 1994, Collins 1997).

Leading multinational brands increasingly require suppliers to deploy participatory management practices to promote manager-worker dialogue, from joint planning procedures to unions. Target states in its supplier code of corporate responsibility that it "expects suppliers to productively engage workers and value them as critical assets to sustainable business success. This includes respecting the rights of workers to freely associate, engage in worker participation groups and submit individual grievances without fear of retaliation" (Target 2018). Reebok (now a part of Adidas) required its suppliers to develop worker empowerment programs that train workers on their legal rights, provide channels for communication with both management and factory monitors about concerns, and foster collective worker representation (Yu 2009).

Among these worker participation practices, unions have been the most important formal channel for worker participation in management processes. To date, scholars, particularly those studying the Americas and the European Union, have focused on unions' political role in rectifying power imbalances between workers and employers (Reilly et al. 1995, Rodriguez-Garavito 2005, Morantz 2009). However, unions play a different role in many of the developing countries where supply chain factories are located. First, workers in many such countries are routinely denied bottom-up representation of their choosing (Anner 2012, Anner and Liu 2016, Bartley and Egels-Zandén 2016). Second, employers that permit unions often do so merely to curry political favor with the authoritarian state rather than to give workers any meaningful voice (Brown and O'Rourke 2007, Friedman and Lee 2010). In countries such as China and Vietnam, unions are considered extensions of the government rather than independent representatives of workers' interests (Anner and Liu 2016), raising serious questions about whether they will be associated with improvements in labor standards.

Yet, by focusing on the relative political impotence of unions in certain environments, these accounts have neglected other important managerial functions unions can play in suppliers. In fact, unions can play an effective communication role that facilitates dialogue between managers and workers and enables workers to help improve production processes and rectify issues. First, unions can provide an additional communication channel for workers to bring hazards to management's attention, one that is often safer and more effective than doing so directly. Many workplace hazards would not be known to managers absent communication with affected workers. For example, in some Chinese factories, unions have input on monitoring occupational health and safety conditions by having a union member serve as a labor protection investigator on the shop floor (Chen and Chan 2004). Such practices facilitate employee reports of health and safety concerns. Research has also found that unions put forth proposals to remedy unsafe and hazardous conditions (Chen and Chan 2004) and 
cooperate directly with management to monitor and correct those conditions (Reilly et al. 1995, Walters 2006).

Second, in many factories, unions provide a vehicle for communicating information about occupational health and safety to workers. Indeed, research has shown that in unionized factories, workers are more aware of dangerous practices (Gillen et al. 2002). In China, studies have found that unions are often tasked with educating employees on workplace conditions and workers' wellbeing, which can help train frontline workers to identify and to protect themselves from occupational hazards (Dong et al. 2004, Nissen et al. 2008). By engaging and educating workers, unions can assist in improving production processes and in identifying and rectifying workplace issues, thus improving labor practices. For these reasons, we hypothesize the following:

Hypothesis $\mathbf{2 b}$. Labor codes of conduct will be more tightly coupled to labor practices in suppliers with workers' unions than in suppliers without workers' unions.

\section{Interactions Among Efficiency and Managerial Structures}

The existing literature suggests that internally buffered structures will be isolated from the technical core of the organization (Bromley and Powell 2012) or from one another (Binder 2007). This claim is in some tension with research on institutional complexity and institutional scholarship demonstrating that organizational structures can be mutually constituting. Studies have demonstrated, for instance, that organizational structures based on very different logics can coexist within organizations and, under certain conditions, can become intertwined (Besharov and Smith 2014). Neoinstitutional scholars have similarly demonstrated that organizational conceptions of efficiency and compliance with legal norms can shape one another (Dobbin and Sutton 1998). Thus, particularly in organizations with managerial structures that emphasize improving organizational processes and fostering interunit dialogue, one would expect mutual influence among organizational structures rather than isolation. We hypothesize above that efficiency structures will buffer the internal impact of legitimacy structures like codes of conduct that seek to change labor practices in ways that could undermine productivity and conversely that managerial structures like certification and unions will be associated with tighter coupling of codes and labor practices. But what is the relationship of efficiency and managerial structures to one another? And how does their interaction relate to such coupling?

\section{Managerial Structures Mitigate Buffering by Efficiency} Structures. We argue that managerial structures will attenuate the negative relationship between efficiency structures and the coupling of labor codes and practices. Research suggests that multiple organizational structures reflecting different logics can become compatible with each other, especially when they are aligned in realizing organizational goals (e.g., Binder 2007, Besharov and Smith 2014). In our context, the looser coupling between labor practices and labor codes associated with efficiency structures is particularly likely to be tempered when a process improvement approach and intraorganizational dialogue fostered by managerial structures can help the organization reconcile legitimacy and efficiency demands. Specifically, we posit that both certification and unions can help alleviate the perceived conflict between codes of conduct and production efficiency, especially in the presence of structures that emphasize such efficiency.

As discussed previously, the pursuit of high-volume production and short-term economic rewards under high-powered productivity incentives can discourage practices that would improve labor practices at some cost to productivity. However, certification to management system standards can help suppliers develop and sustain production practices that ultimately improve productivity and reduce the marginal costs of compliance, which, in turn, can improve labor practices. For example, adopting quality management systems may improve production planning and reduce cycle time (Dunlop and Weil 1996, Appelbaum 2000), which, in turn, may reduce the pressure on workers to work overtime (Locke et al. 2009). Thus, by improving production process management, suppliers may reduce the cost of remediating certain violations of workplace standards. Furthermore, the management process improvements associated with lean production have been shown to increase productivity and quality (Holweg 2007) while also reducing noncompliance with supplier codes of conduct (Distelhorst et al. 2016). Such production practices can alleviate the underlying tension between shortterm economic rewards and labor code compliance in high-productivity-oriented contexts.

We posit that unions, too, can attenuate the negative relationship between high-powered productivity incentives and the coupling of labor codes of conduct and labor practices. First, unions often educate workers on occupational hazards, the costs they would bear from workplace injuries, and their legal rights (Meng and Smith 1993, Morse et al. 2003), which can countervail the incentive to cut corners in pursuit of rapid production. Second, unions are associated with longer job tenure (Freeman 1980, Bender and Sloane 1999), which increases the chance that managers will invest in worker training and other programs that improve both labor practices and productivity, but only over the long term. Workers similarly may be more likely to support such practices if they expect to be around long enough to benefit from them, which can, in turn, increase the likelihood that managers will invest in them. In addition, in domestic contexts where many suppliers in our sample are 
located, unions are used as a vehicle for reconciling social goals with business interests (Zajak 2017). Therefore, we hypothesize the following:

Hypothesis 3a. Being certified to management system standards attenuates the looser coupling of labor codes of conduct and labor practices associated with high-powered productivity incentive structures.

Hypothesis $3 \mathbf{b}$. Workers' unions attenuate the looser coupling of labor codes of conduct and labor practices associated with high-powered productivity incentive structures.

\section{Efficiency Structures Temper Coupling by Managerial} Structures. We hypothesized above that managerial structures can mitigate the looser coupling of labor codes and practices that we observe when efficiency structures act as a buffer. Here, we posit the inverse relationship, that efficiency structures can temper the positive association between managerial structures and the coupling of labor codes and labor practices. Existing literature suggests that when multiple organizational structures reflecting different logics coexist within an organization, the structure that is core to the organizational tasks and operations is likely to dominate, diminishing or marginalizing other structures (Thornton et al. 2012, Besharov and Smith 2014). In the global value chain context, as we argued above, efficiency demands are paramount. In suppliers that maintain high-powered productivity incentives, labor productivity is prioritized at the expense of improved labor practices. For example, managers at piece-rate suppliers are less likely to take workers off the line to engage in comprehensive training that would teach continuous improvement techniques (e.g., to identify hazards and learn safer work procedures) or internal assessment and review meetings that would foster interunit dialogue. Similarly, workers at such suppliers might be more reluctant to provide input and engage in communication that might even temporarily impede productivity. Thus, we posit that efficiency structures like piece-rate payment incentives will attenuate the positive relationship between managerial structures like certification and unions and code compliance improvement.

Hypothesis 3c. High-powered productivity incentive structures attenuate the tighter coupling of labor codes of conduct and labor practices associated with being certified to management system standards.

Hypothesis 3d. High-powered productivity incentive structures attenuate the tighter coupling of labor codes of conduct and labor practices associated with being unionized.

Managerial Structures Complement Each Other. Prior scholarship has argued that management systems to protect workers are more likely to succeed when they are supported by workers who can provide information, monitoring, and advocacy (Rodriguez-Garavito 2005, Anner et al. 2013) - that is, that the relationship is complementary. Yet, another strand of research suggests that the relationship is substitutive by arguing that certified management systems are designed to displace union interventions (Esbenshade 2004, Bartley 2005) or to substitute for ineffective unions (Locke et al. 2013). In the context of global supply chain factories, we argue that unions and certified management systems are complementary in their association with tighter coupling between labor codes and labor practices because together they provide more comprehensive communication channels and richer input across the organization.

On the one hand, certified management systems tend to focus on developing communication channels across formal organizational units or departments. As argued previously, certified management systems can engage multiple units and management teams in ongoing internal assessments, continuous improvement efforts, and corrective action procedures. These activities provide formal channels for workers' unions to bring workplace hazards to management's attention in a systematic manner, magnifying their efforts to broadcast these concerns to multiple units across the organization, and enhancing workers' unions' communication role. In addition, these internal assessment and review meetings can also convey integrated messages from multiple units to workers' unions, which can then deliver more comprehensive information and useful training to workers.

On the other hand, unions tend to focus on fostering communication channels across organizational constituencies (rather than units) and enriching the content of communication by cultivating input from workers. For instance, unions can collect from frontline workers information related to issue identification, risk assessment, and procedure updates, which in turn can improve the implementation of management systems. In addition, the union's educational and communicative roles can raise workers' awareness of management system standards and engagement in certain certification programs ( $\mathrm{O}^{\prime}$ Rourke 2003, Rodriguez-Garavito 2005, Yu 2009), enhancing the usefulness of worker input about the implementation of these programs. Because the value of each of these managerial structures depends, jointly, on both the availability of communication channels and the quality of dialogue flowing through them, we hypothesize the following:

Hypothesis $4 a$. Being certified to management system standards enhances the coupling of labor codes of conduct and labor practices associated with being unionized.

Hypothesis $4 \mathbf{b}$. Workers' unions enhance the coupling of labor codes of conduct and labor practices associated with being certified to management system standards. 


\section{Data and Measures}

We test our hypotheses using a proprietary data set from a large social auditing firm that required anonymity as a condition of sharing its data. The Europe-based multinational firm has tens of thousands of employees based in hundreds of offices around the world. It is a wellrecognized inspection and product testing agency, is accredited to conduct certification assessments of several leading codes of conduct standards in the industry, and also conducts social auditing assessments of its clients' proprietary supplier codes of conduct. The data set includes all audits against a single code of conduct that the firm conducted from 2012 through 2015. The time gap between suppliers' successive audits averaged 9 months and ranged from 2.4 months to 14.5 months. ${ }^{2}$ The data set also provides characteristics (but not the names) of each audited supplier, ${ }^{3}$ the audit team, and the buyer on whose behalf the audit was conducted.

Because our empirical specification includes a supplier's focal (current) audit and its prior audit, our estimation sample is limited to those suppliers with at least two audits in our data set. For our primary analysis, we omit 769 suppliers (about 17\% of the full data set) that report information about the presence of a workers' union, piece-rate payment, or certification that is inconsistent between the prior and focal audits because of concerns about potential endogeneity associated with their adoption during our sample period. Doing so results in our hypothesized variables in our primary analysis being identified based on differences between (not within) suppliers, an approach suitable for our correlational analysis. ${ }^{4}$ Our estimations are based on 4,887 focal audits of 3,276 suppliers in 55 countries on behalf of 102 buyers from 11 countries. Because our specification also relies on data from each supplier's prior audit, our analysis is based on a total of 8,323 focal and prior audits. ${ }^{5}$ Table A1 of Online Appendix A reports the industry composition of our sample: the most common industries are hardlines (merchandise such as furniture, household utensils, and home décor), apparel, and electronics. As Table A2 of Online Appendix A shows, most of the audited suppliers are in China; the rest are elsewhere in Asia, Europe, and the Americas.

\section{Dependent Variable}

In our context, audit teams assess the extent to which suppliers' workplace conditions meet a single code of conduct that specifies maximum working hours and minimum wages, occupational health and safety practices, and environmental management practices. This standard is highly consistent with international consensus standards such as the International Labour Organization (ILO) core labor standards. ${ }^{6}$ During the audit, auditors review documentation, interview employees who are randomly selected by auditors, and conduct onsite inspections to assess the actual state of affairs on the shop floor. Each audit results in a labor practice score, a summary score of all aforementioned code of conduct categories, that ranges from 0 to 100, with higher scores indicating that labor practices better adhere to the code and thus tighter coupling. In our sample, scores range from 19 to 100 , the average being 79 .

Our dependent variable measures a supplier's labor practice improvement between its prior and focal audits, calculated by subtracting the prior audit's labor practices score from the focal audit's score. Larger values indicate greater improvement and thus an increase in coupling between labor practices and labor codes of conduct. In our sample, improvement averages 6 and ranges from -62 to 67.7

\section{Independent Variables}

We identify factories that use high-powered productivity incentives by coding piece-rate payment, a dichotomous variable, as 1 when the supplier pays its frontline workers on a piece rate, and 0 otherwise. ${ }^{8}$ We code certification to a management system standard as 1 when a supplier is certified to at least one standard-such as SA8000, WRAP, ISO 9001, or OHSAS 18001-at the time it is audited, ${ }^{9}$ and 0 otherwise. Workers' union, another dichotomous variable, equals 1 when the supplier is unionized, as recorded by the auditor, and 0 otherwise. Data for these three variables were obtained from the audit database. In our model, we use lagged values so that they pertain to the supplier's prior audit to examine their effect on subsequent improvement. Fifteen percent of these prior audits were conducted at certified suppliers, ${ }_{10}^{10} 26 \%$ at unionized suppliers, and $11 \%$ at suppliers that use piece-rate payment.

\section{Control Variables}

Audit Level. We control for several audit-level factors that might influence the extent to which suppliers improve labor practices. We include labor practice score (prior audit) because suppliers with lower prior scores have more room for improvement-and might face less expensive improvement opportunities-than those that already had superior labor practices. We also control for audit sequence with a series of dummies denoting the supplier's first audit in the sample, the second, and so on, because suppliers may face increasing remediation costs and difficulties in subsequent audits. Whether the supplier is paying for the audit can also influence auditors' reports because of the conflict of interest that might lead auditors to report fewer violations when the audit is paid for by the supplier rather than the buyer (Short et al. 2016). We therefore create two dummy variables, paid by buyer (prior audit) and paid by buyer (focal audit), to distinguish those audits from those paid for by the supplier itself.

We control for several characteristics of audit teams that prior research has shown can affect audit scores 
(Short et al. 2016). First, we create dummy variables to control for the gender composition of the audit teams that conducted the supplier's prior and focal audits: allfemale audit team and mixed-gender audit team, with allmale audit team as the omitted category. Second, we control for audit team average age for the prior and focal audits, based on auditor age data provided by the auditing firm. Third, we control for audit team maximum tenure - the most years that any member of the audit team had worked at the auditing firm-for the prior and focal audits. ${ }^{11}$

Supplier Level. We control for supplier size because larger factories, being more visible, are exposed to higher regulatory pressures (Surroca et al. 2013), which could increase their willingness to improve. We measure supplier size as the number of employees, obtained from the auditing company, which we log to reduce skew. We also control for supplier age by adding 1 to the difference between the audit year and the factory's founding year. We top-code the values at the 99th percentile of the sample distribution (68) to reduce the potential impact of outliers, then use the $\log$ to reduce skew.

We control for several other factors that might influence a supplier's improvement rate. Migrant workers are more likely to be exploited and mistreated while local workers tend to demand better working conditions (Flanagan 2006). Managers in factories with a higher proportion of local workers (compared with migrant workers) might therefore face more pressure to improve labor practices. In contrast, some factories might invest in improving labor practices to better attract migrant workers. These competing concerns lead us to control for local worker ratio in the supplier factory, operationalized as the percentage of frontline employees who are local, based on audit data. Gender differences in the workforce might also influence improvement rates. Some studies suggest that female workers in laborintensive industries are docile and complain less (e.g., Caraway 2007), which implies that workplaces with a greater proportion of female employees might improve less because there will be less pressure to remedy harmful conditions. However, other studies argue that female employees resist exploitive workplace conditions and actively exercise their rights (e.g., Rock 2003, Elias 2005), which implies that workplaces with a greater proportion of female employees might improve more. The possibility that the gender composition of the workforce might influence improvement rates in one direction or the other leads us to control for female worker ratio in the supplier factory, operationalized as the percentage of frontline employees who are women. Furthermore, some factories outsource part of their production to subcontractors to evade health and safety requirements (O'Rourke 2003). Because factories that subcontract might improve more if they outsource problems, we include a dummy variable use subcontractors, which we code based on audit data.

\section{Estimation and Results}

The aforementioned independent variables and control variables can influence labor practice scores in both the prior and focal audits. Therefore, to predict improvement, we need to account for these factors for both audits. We include audit team characteristics-gender composition, average age, and maximum tenure-for both. ${ }^{12}$ However, because the supplier-level variables are very stable, including them for both audits would substantially increase multicollinearity without adding meaningful controls. ${ }^{13}$ Therefore, we include them only for the prior audit.

We include industry and year fixed effects to control for potential differences in improvement rate between suppliers in different industries and between various years in our sample. Because research shows that governmental, economic, and civil society attributes of buyers' headquarters country can influence their attentiveness to supply chain conditions, which can in turn affect the pressure they exert on suppliers to comply to labor standards (Toffel et al. 2015), we construct dummy variables for each buyer's headquarters country. ${ }^{14}$

\section{Results}

Summary statistics are reported in Table 1; descriptive statistics and correlations are reported in Tables A1-A3 of Online Appendix A. We test our hypotheses using ordinary least squares (OLS) regression, clustering standard errors by the supplier's country (a more conservative approach than clustering by supplier), and report results in Table $2 .{ }^{15}$ Model 1 tests our direct-effect hypotheses (Hypotheses 1, 2a, and 2b). The statistically significant negative coefficient on piece-rate payment (prior audit) $(\beta=$ $-3.59, p<0.01)$ reveals that factories paying workers on a piece-rate basis improve less on average than other factories, which supports Hypothesis 1. Predictive margins indicate that suppliers that used piece-rate payment improved their audit score in successive audits by 3.0 points on average, less than half the 6.6-point average improvement among suppliers that did not use piece-rate payment.

The statistically significant positive coefficient on certification (prior audit) $(\beta=0.98, p<0.01)$ indicates that suppliers certified to management system standards improve more than noncertified suppliers, which supports Hypothesis 2a. Predictive margins indicate that certified suppliers improved by an average of 7.0 points, $17 \%$ more than the 6.0 -point average improvement of noncertified suppliers.

The statistically significant positive coefficient on workers' union (prior audit) $(\beta=1.18, p<0.01)$ indicates that unionized suppliers improve more than nonunionized suppliers, which supports Hypothesis 2b. Predictive 
Table 1. Summary Statistics

\begin{tabular}{|c|c|c|c|c|}
\hline & Mean & Standard deviation & Minimum & Maximum \\
\hline Labor practice score (focal audit) & 78.83 & 16.19 & 19.22 & 100 \\
\hline Improvement & 6.19 & 16.53 & -62.42 & 66.55 \\
\hline Piece-rate payment (prior audit) & 0.11 & 0.31 & 0 & 1 \\
\hline Certification (prior audit) & 0.15 & 0.36 & 0 & 1 \\
\hline Workers' union (prior audit) & 0.26 & 0.44 & 0 & 1 \\
\hline Labor practice score (prior audit) & 72.65 & 17.33 & 16.05 & 100 \\
\hline Paid by buyer (prior audit) & 0.33 & 0.47 & 0 & 1 \\
\hline Paid by buyer (focal audit) & 0.33 & 0.47 & 0 & 1 \\
\hline All-female team (prior audit) & 0.34 & 0.47 & 0 & 1 \\
\hline All-female team (focal audit) & 0.36 & 0.48 & 0 & 1 \\
\hline Mixed-gender team (prior audit) & 0.14 & 0.35 & 0 & 1 \\
\hline Mixed-gender team (focal audit) & 0.12 & 0.32 & 0 & 1 \\
\hline Audit team average age (prior audit) & 30.80 & 4.89 & 24.70 & 47 \\
\hline Audit team average age (focal audit) & 31.03 & 5.04 & 24.50 & 47 \\
\hline Audit team maximum tenure (prior audit) & 3.82 & 2.70 & 0.69 & 10.48 \\
\hline Audit team maximum tenure (focal audit) & 4.00 & 2.75 & 0.72 & 10.48 \\
\hline Audit sequence & 2.73 & 1.01 & 2 & 6 \\
\hline Supplier's size (prior audit) ${ }^{\mathrm{L}}$ & 5.21 & 1.30 & 1.79 & 9.62 \\
\hline Supplier's age (prior audit) ${ }^{\mathrm{L}}$ & 2.22 & 0.74 & 0 & 4.22 \\
\hline Female worker ratio (prior audit) & 0.57 & 0.20 & 0 & 1 \\
\hline Local worker ratio (prior audit) & 0.49 & 0.40 & 0 & 1 \\
\hline Use subcontractors (prior audit) & 0.19 & 0.39 & 0 & 1 \\
\hline
\end{tabular}

margins indicate that unionized suppliers improved by 7.1 points, $20 \%$ more than the 5.9 -point average improvement of nonunionized suppliers.

We test Hypothesis 3a and Hypothesis 3c with Model 2, which adds the interaction between piece-rate payment (prior audit) and certification (prior audit). Pairwise comparison of predictive margins reveals that piece-rate payment factories that are not certified to management system standards improve by an average of 2.6 points ( $42 \%$ of the 6.2 -point sample mean), whereas piece-rate payment factories that are certified improve by an average of 4.7 points ( $76 \%$ of the sample mean), a statistically significantly difference $(F=18.48, p<0.01)$. These results support the prediction of Hypothesis $3 a$ that certification to a management system standard significantly attenuates the negative association between piece-rate payment and the coupling of labor codes and labor practices. Furthermore, certified factories that do not use piece-rate payment improve by an average of 7.2 points ( $116 \%$ of the sample mean), statistically significantly more than the average 4.7point improvement of certified factories that use piecerate payment $(F=10.39, p<0.01)$. These results support the prediction of Hypothesis $3 c$ that piece-rate payment significantly attenuates the positive association between certification to management system standards and the coupling of labor codes and labor practices. Figure A1 of Online Appendix A graphs these average predicted effects along with their $95 \%$ confidence intervals.

We test Hypothesis $3 \mathrm{~b}$ and Hypothesis $3 \mathrm{~d}$ with Model 3, which adds to our base model the interaction between piece-rate payment (prior audit) and workers' union (prior audit). Pairwise comparison of predictive margins reveals that nonunionized piece-rate payment factories improved an average of 2.1 points (34\% of the sample mean), whereas unionized piece-rate payment factories improved an average of 4.6 points $(74 \%$ of the sample mean), a statistically significant difference $(F=25.5, p<$ 0.01). These results, depicted in Figure A2 of Online Appendix A, support the prediction of Hypothesis $3 \mathrm{~b}$ that workers' unions significantly attenuate the negative association between piece-rate payment and the coupling of labor codes and labor practices. Furthermore, unionized factories that do not use piece-rate payment improve an average of 7.3 points $(118 \%$ of the sample mean), statistically significantly more than the average 4.6-point improvement of unionized piece-rate payment factories $(F=10.22, p<0.01)$. These results, also depicted in Figure A2 of Online Appendix A, support the prediction of Hypothesis $3 \mathrm{~d}$ that piece-rate payment significantly attenuate the positive association between piece-rate payment and the coupling of labor codes and labor practices.

We test Hypothesis 4a and Hypothesis 4b with Model 4, which adds to our base model the interaction between certification (prior audit) and workers' union (prior audit). Pairwise comparison of predictive margins reveals that certified unionized factories averaged 9.2-point improvement, whereas noncertified unionized factories improved by an average of 6.4 points, a statistically significant difference $(F=23.46 ; p<0.01$; also see Figure A3 of Online Appendix A). This supports the prediction of 
Table 2. Regression Results

\begin{tabular}{|c|c|c|c|c|}
\hline Dependent variable: Improvement & (1) & (2) & (3) & $(4)$ \\
\hline Piece-rate payment (prior audit) & $\begin{array}{l}-3.588^{* * *} \\
(0.838)\end{array}$ & $\begin{array}{l}-3.842^{* * *} \\
(0.901)\end{array}$ & $\begin{array}{l}-4.168^{* * *} \\
(0.815)\end{array}$ & $\begin{array}{l}-3.623^{* * *} \\
(0.871)\end{array}$ \\
\hline Certification (prior audit) & $\begin{array}{l}0.977^{* * *} \\
(0.196)\end{array}$ & $\begin{array}{l}0.804^{* *} \\
(0.231)\end{array}$ & $\begin{array}{l}0.958^{* * *} \\
(0.192)\end{array}$ & $\begin{array}{c}-0.262 \\
(0.379)\end{array}$ \\
\hline Workers' union (prior audit) & $\begin{array}{l}1.177^{* * *} \\
(0.127)\end{array}$ & $\begin{array}{l}1.164^{* * *} \\
(0.132)\end{array}$ & $\begin{array}{l}0.962^{* * *} \\
(0.122)\end{array}$ & $\begin{array}{c}0.527^{*} \\
(0.249)\end{array}$ \\
\hline Piece-rate payment (prior audit) $\times$ Certification (prior audit) & & $\begin{array}{l}1.327^{*} \\
(0.615)\end{array}$ & & \\
\hline Piece-rate payment (prior audit) $\times$ Workers' union (prior audit) & & & $\begin{array}{l}1.489^{* *} \\
(0.487)\end{array}$ & \\
\hline Certification (prior audit) $\times$ Workers' union (prior audit) & & & & $\begin{array}{l}3.068^{* *} \\
(0.913)\end{array}$ \\
\hline Labor practice score (prior audit) & $\begin{array}{l}-0.603^{* * *} \\
(0.006)\end{array}$ & $\begin{array}{l}-0.603^{* * *} \\
(0.006)\end{array}$ & $\begin{array}{l}-0.603^{* * *} \\
(0.006)\end{array}$ & $\begin{array}{l}-0.603^{* * *} \\
(0.006)\end{array}$ \\
\hline Paid by buyer (prior audit) & $\begin{array}{c}0.169 \\
(0.299)\end{array}$ & $\begin{array}{c}0.173 \\
(0.299)\end{array}$ & $\begin{array}{c}0.153 \\
(0.301)\end{array}$ & $\begin{array}{c}0.178 \\
(0.292)\end{array}$ \\
\hline Paid by buyer (focal audit) & $\begin{array}{c}0.978^{*} \\
(0.448)\end{array}$ & $\begin{array}{c}0.974^{*} \\
(0.449)\end{array}$ & $\begin{array}{c}0.975^{*} \\
(0.450)\end{array}$ & $\begin{array}{c}0.986^{*} \\
(0.443)\end{array}$ \\
\hline All-female team (prior audit) & $\begin{array}{c}-0.138 \\
(0.221)\end{array}$ & $\begin{array}{c}-0.145 \\
(0.220)\end{array}$ & $\begin{array}{c}-0.124 \\
(0.221)\end{array}$ & $\begin{array}{c}-0.170 \\
(0.220)\end{array}$ \\
\hline All-female team (focal audit) & $\begin{array}{c}-0.576^{*} \\
(0.218)\end{array}$ & $\begin{array}{r}-0.574^{*} \\
(0.217)\end{array}$ & $\begin{array}{c}-0.573^{*} \\
(0.220)\end{array}$ & $\begin{array}{c}-0.593^{* *} \\
(0.215)\end{array}$ \\
\hline Mixed-gender team (prior audit) & $\begin{array}{l}1.656^{*} \\
(0.697)\end{array}$ & $\begin{array}{l}1.664^{*} \\
(0.694)\end{array}$ & $\begin{array}{l}1.691^{*} \\
(0.696)\end{array}$ & $\begin{array}{r}1.708^{*} \\
(0.700)\end{array}$ \\
\hline Mixed-gender team (focal audit) & $\begin{array}{l}-4.302^{* * *} \\
(0.748)\end{array}$ & $\begin{array}{l}-4.300^{* * *} \\
(0.745)\end{array}$ & $\begin{array}{l}-4.302^{* * *} \\
(0.742)\end{array}$ & $\begin{array}{l}-4.266^{* * *} \\
(0.734)\end{array}$ \\
\hline Audit team average age (prior audit) & $\begin{array}{c}-0.074 \\
(0.050)\end{array}$ & $\begin{array}{c}-0.074 \\
(0.050)\end{array}$ & $\begin{array}{c}-0.072 \\
(0.051)\end{array}$ & $\begin{array}{c}-0.079 \\
(0.052)\end{array}$ \\
\hline Audit team average age (focal audit) & $\begin{array}{l}0.114^{* *} \\
(0.038)\end{array}$ & $\begin{array}{l}0.114^{* *} \\
(0.038)\end{array}$ & $\begin{array}{l}0.114^{* *} \\
(0.039)\end{array}$ & $\begin{array}{l}0.112^{* *} \\
(0.038)\end{array}$ \\
\hline Audit team maximum tenure (prior audit) & $\begin{array}{l}0.305^{* * *} \\
(0.056)\end{array}$ & $\begin{array}{l}0.306^{* * *} \\
(0.056)\end{array}$ & $\begin{array}{l}0.302^{* * *} \\
(0.056)\end{array}$ & $\begin{array}{l}0.305^{* * *} \\
(0.056)\end{array}$ \\
\hline Audit team maximum tenure (focal audit) & $\begin{array}{l}-0.307^{* * *} \\
(0.066)\end{array}$ & $\begin{array}{l}-0.306^{* * *} \\
(0.066)\end{array}$ & $\begin{array}{l}-0.308^{* * * *} \\
(0.065)\end{array}$ & $\begin{array}{l}-0.310^{* * *} \\
(0.065)\end{array}$ \\
\hline Supplier's size (prior audit) ${ }^{\mathrm{L}}$ & $\begin{array}{c}0.281^{*} \\
(0.138)\end{array}$ & $\begin{array}{c}0.283^{*} \\
(0.139)\end{array}$ & $\begin{array}{c}0.285^{*} \\
(0.138)\end{array}$ & $\begin{array}{c}0.289^{\dagger} \\
(0.145)\end{array}$ \\
\hline Supplier's age (prior audit) $)^{\mathrm{L}}$ & $\begin{array}{c}-0.013 \\
(0.154)\end{array}$ & $\begin{array}{c}-0.012 \\
(0.155)\end{array}$ & $\begin{array}{c}-0.001 \\
(0.153)\end{array}$ & $\begin{array}{c}-0.005 \\
(0.152)\end{array}$ \\
\hline Female worker ratio (prior audit) & $\begin{array}{l}3.842^{* * *} \\
(0.382)\end{array}$ & $\begin{array}{l}3.876^{* * *} \\
(0.379)\end{array}$ & $\begin{array}{l}3.825^{* * *} \\
(0.378)\end{array}$ & $\begin{array}{l}3.972^{* * *} \\
(0.390)\end{array}$ \\
\hline Local worker ratio (prior audit) & $\begin{array}{c}-0.360^{* * *} \\
(0.096)\end{array}$ & $\begin{array}{c}-0.361^{* * *} \\
(0.096)\end{array}$ & $\begin{array}{c}-0.332^{* * *} \\
(0.094)\end{array}$ & $\begin{array}{c}-0.415^{* * *} \\
(0.100)\end{array}$ \\
\hline Use subcontractors (prior audit) & $\begin{array}{c}0.012 \\
(0.669)\end{array}$ & $\begin{array}{c}0.002 \\
(0.666)\end{array}$ & $\begin{array}{c}0.026 \\
(0.670)\end{array}$ & $\begin{array}{c}0.022 \\
(0.673)\end{array}$ \\
\hline $\begin{array}{l}\text { Observations } \\
R^{2}\end{array}$ & $\begin{array}{c}4,887 \\
0.3983\end{array}$ & $\begin{array}{c}4,887 \\
0.3984\end{array}$ & $\begin{array}{c}4,887 \\
0.3984\end{array}$ & $\begin{array}{c}4,887 \\
0.3992\end{array}$ \\
\hline
\end{tabular}

Notes. Ordinary least squares (OLS) regression coefficients with standard errors clustered by supplier country in parentheses. Industry fixed effects, year fixed effects, audit-sequence fixed effects, supplier-country fixed effects, and buyer-country fixed effects are included.

${ }^{+} p<0.10 ;{ }^{*} p<0.05 ;{ }^{* *} p<0.01 ;{ }^{* * *} p<0.001$ (two-tailed tests).

$\mathrm{L}$ indicates logged.

Hypothesis 4a that workers' unions are associated with greater coupling of labor codes and labor practices (and thus greater labor practice improvement) in certified suppliers than in not-certified suppliers. In addition, the 9.2-point average improvement among certified unionized factories is statistically significantly more than the average 5.6-point improvement of certified nonunionized factories $(F=23.52 ; p<0.01$; also see 
Figure A3 of Online Appendix A). This supports the prediction of Hypothesis $4 \mathrm{~b}$ that certification is associated with greater coupling of labor codes and labor practices (and thus greater labor practice improvement) in unionized suppliers than in nonunionized suppliers.

Turning to our control variables, we find strong evidence that improvement rates significantly differ by industry (see Table B1 of Online Appendix B), year, audit-sequence, and buyer country (each of four Wald tests rejects the equality of each set of fixed effects at $p<$ 0.01 ). Consistent with the notion that high performers face fewer or more expensive opportunities to improve, we find that factories with higher baseline scores exhibit less improvement, as evidenced by a significant negative coefficient on labor practice score (prior audit).

Regarding audit team characteristics, we first examine the effects of the focal audit team, which are interpreted as leniency that influences the current audit score element of improvement. Our results yield negative coefficients on all-female team (focal audit), mixed-gender team (focal audit), and audit team maximum tenure (focal audit), suggesting that all-male teams and less-experienced teams are more lenient, which is consistent with Short et al. (2016). ${ }^{16}$ Considering the characteristics of prior audit teams, we find more improvement among factories whose prior audit teams were more experienced (confirming Hugill et al. 2018) and that were mixed gender. ${ }^{17}$

Regarding the payment party and noting that paid by buyer (focal audit) and paid by buyer (prior audit) are highly correlated ( $\rho=0.74$, per Table A3), our reestimation shows that coefficients reported in Table 2 on paid by buyer (prior audit) and paid by buyer (focal audit) are driven by multicollinearity and should thus be interpreted with caution. ${ }^{18}$

Turning to supplier characteristics, significant positive coefficient on supplier's size (prior audit) suggests that larger factories improve more. The significant positive coefficient on female worker ratio (prior audit) indicates that factories with a greater proportion of female workers improve more, which suggests female workers might be more likely to raise concerns about workplace conditions, consistent with studies on female workers' resistance to exploitive labor conditions (e.g., Rock 2003, Elias 2005). The significant negative coefficient on local worker ratio (prior audit) indicates that factories with larger proportions of migrant workers improve more, which suggests that factories might be more motivated to improve labor practices to attract migrant workers than to attract local workers. We find no significant effect of the use of subcontractor labor on improvement.

\section{Robustness Tests}

Online Appendix $C$ reports further analyses to assess the robustness of our results. First, we assess whether controlling for whether an audit is announced or unannounced affects our results, as prior research indicates that it can influence improvement rates (Hugill et al. 2018). We added two dummy control variables, announced (prior audit) and announced (focal audit), to our primary models and estimated them on the subsample of audits (those conducted in 2014 and 2015) for which our data set includes announcement information (see Table C1). Second, we assess whether the time gap between suppliers' prior and focal audits influenced our results by testing our hypotheses on a new dependent variable, improvement per month (see Table C2). Third, because more powerful buyers might be more successful at coercing their suppliers to improve labor practices, we control for this by including admittedly crude proxies for buyer power (total number of facilities audited for each buyer and its square in Table C3 and log in Table C4). Fourth, all models (including ours) that predict a difference score while controlling for the lagged score assume there is no contemporaneous correlation between the lagged score and the error term (that is, between $y_{i, t-1}$ and $\left.\varepsilon_{i, t}\right)$. As a robustness test, we estimate an alternative set of models that predict $\ln \left(y_{i, t} / y_{i, t-1}\right)$ and control for $\ln \left(y_{i, t-1}\right)$ instead of $y_{i, t-1}$, which assumes no contemporaneous correlation between the lagged log score $\left(\ln \left(y_{i, t-1}\right)\right)$ and the error term $\left(\varepsilon_{i, t}\right)$ resulting from predicting $\ln \left(y_{i, t} / y_{i, t-1}\right)$ conditional on $\ln \left(y_{i, t-1}\right)$. All of these robustness test results support our hypotheses. Lastly, in our primary analysis, we compare variations between suppliers using a cross-sectional approach, and here we test whether our theory holds by examining variations within suppliers with supplier fixedeffects models. The coefficients on the hypothesized variables in these supplier fixed-effects models are identified exclusively by instances in which suppliers adopted (or dropped) piece-rate payment, certification, and/or unions. As such, these coefficients are generated by an entirely different set of suppliers from our main sample. This set of supplier fixed-effects models yields results that are largely consistent with our main models, which increases the external validity of our theory.

\section{Supplemental Analysis: Prescriptive vs. Generative Management Systems}

In the above analyses, we treat management system standards certification generically, focusing on the interunit dialogue improvement features common to these regimes. However, different regimes have different degrees of emphasis on process improvement versus compliance with prescriptive, substantive rules. We conducted supplemental analyses to investigate whether certifications that differ in this regard also differ in their relationship to the coupling of codes of conduct and supplier labor practices.

Several of the certification programs in our sample prescribe substantive rules with which suppliers must comply to obtain certification. For example, the Business Social Compliance Initiative (BSCI) management system 
standard includes a code of conduct requiring fair remuneration and observance of specified occupational health and safety rules and prohibiting child labor and forced labor. Worldwide Responsible Accredited Production (WRAP) mandates adherence to 12 "Production Principles" similarly protecting workers' rights. These management systems provide externally imposed prescriptive rules, and suppliers certified to these systems are audited primarily to ensure they fully comply with these substantive rules. We define these as "prescriptive" certifications and code the variable prescriptive certification (prior audit) as 1 when the audited supplier has been certified to at least one of them, and 0 otherwise.

In contrast, we define "generative" certifications as those that lack prescriptive rules and instead require the organization to identify and develop its own objectives in the production process based on risk assessment practices and to update these objectives through periodic review. For instance, ISO 9001 places responsibility on the certified organization to "establish the objectives and processes necessary to deliver results" (ISO 90012000: vi), and ISO 14001 stresses that objectives may differ across organizations (ISO 14001-1996). We code the variable generative certification (prior audit) as 1 when the audited supplier is certified to at least one such system, and 0 otherwise. (Table D1 of Online Appendix D lists the prescriptive and generative certifications in our sample.)

Replacing our single certification variable with these two certification variables yields a positive and significant coefficient on generative certification (prior audit) and a nonsignificant coefficient on prescriptive certification (prior audit). The results, reported as Model 1 of Table D2 (Online Appendix D), indicate that generative certification is associated with improvements in supplier labor practices, but no evidence that prescriptive certification is. We also analyze the relationship between these two certification variables and labor practice levels (that is, the labor practice scores reported in focal audits) and report results as Model 2 of Table D2. Both certification variables are positively associated with superior labor practice levels. Yet, as Model 1 shows, only generative certifications are associated with improvement. These findings offer additional support for our argument that it is an emphasis on the development of organizational processes that facilitate cross-organizational dialogue that explains the positive association between managerial structures and the coupling of codes of conduct and labor practices. In the Discussion section, we discuss the implications of these findings in greater detail.

\section{Discussion}

Our study reveals important insights about the internal structural conditions under which codes of conduct are more likely to be coupled with improvements in labor practices and the extent to which core production activities are more likely to be buffered from codes by other organizational structures. First, we find that labor standards are less coupled to labor practices in suppliers with high-powered productivity incentive structures. Second, coupling is tighter in the presence of two managerial structures: certified management systems and unions. Third, we identify important dependencies between these organizational structures: management system certifications and unions attenuate the looser coupling of labor codes and labor practices associated with high-powered productivity incentive structures, while high-powered productivity incentive structures also temper the tighter coupling of codes and practices associated with managerial structures. We also find support for the argument that certified management systems and unions complement each other in the coupling of labor standards and practices. These findings contribute in important ways to theory and practice.

\section{Contribution to the Literature on Formal Organizational Structures and Practices}

First, our focus on the internal structural composition of organizations to ascertain how coupling varies across firms in challenging institutional environments significantly extends a body of scholarship that has concentrated largely on the coupling force of institutional factors external to organizations (e.g., Hafner-Burton and Tsutsui 2005, Bromley and Powell 2012, Bartley and Egels-Zandén 2016). We find that even in emerging economies-where labor regulatory institutions are weak and efficiency demands are strong-some internal structures, such as certification and unions, are associated with tighter coupling of labor codes of conduct and labor practices in suppliers and can attenuate buffering by high-powered productivity incentives. This suggests the need to reconsider the boundary conditions delineating environments in which coupling is more or less likely. Since Meyer and Rowan (1977), the assumption that decoupling is likeliest in less-elaborated institutional environments has shaped the literature and arguably has constrained the parameters of research. Some recent studies finding gaps between companies' formal human rights commitments and their actual practices do not even entertain the possibility that such commitments could be substantive rather than symbolic (Lim and Tsutsui 2012, Berliner and Prakash 2015). This is an important arena for future research.

Second, we investigate the interaction of multiple and potentially competing internal structures. To date, studies have tended to examine the conditions under which a single organizational structure is coupled to or decoupled from organizational practices. But this approach ignores the complex and multifarious nature of these structures inside organizations. Firms face multiple and competing institutional demands that become sedimented into multiple and competing layers of 
organizational structure. It is crucial to appreciate the internal interaction of these structures to understand whether and when they will be coupled to organizational practices. Our attention to the contingent relationships among organizational structures also extends qualitative research on internal (de)coupling processes that, to date, has centered on the activities and interactions of individual actors, such as powerful managers (Fiss and Zajac 2004, Hallett 2010, Overdevest 2010), union representatives (Bartley and Egels-Zandén 2016), a new generation of differently trained personnel (Tilcsik 2010), or boundary-spanning professionals (Edelman 1992, Sutton and Dobbin 1996).

Accounting for how different configurations of internal organizational structures are related to the coupling of legitimacy structures (i.e., labor codes) and organizational practices (i.e., labor practices) allows us to advance theories of internal buffering. Going beyond the stylized idea that legitimacy structures are cordoned off from an organization's core activities, we show that legitimacy structures are not completely isolated from other structures but rather are conditioned by these structures. Specifically, efficiency structures can act as a buffer to shield core labor practices from threatening changes by labor codes, but managerial structures that foster intraorganizational dialogue make it difficult to completely buffer practices from codes. Furthermore, we show important interactions among efficiency structures and managerial structures relating to the buffering of legitimacy structures: efficiency structures temper the reduced buffering of codes associated with managerial structures, managerial structures attenuate the heightened buffering associated with efficiency structures, and multiple managerial structures can complement one another to mitigate the buffering of codes. These findings echo the rising strand of literature on institutional complexity and on organizational hybridity encompassing multiple logics (e.g., Binder 2007, Thornton et al. 2012, Besharov and Smith 2014). Consistent with this literature, we show that efficiency imperatives and legitimacy imperatives can become compatible when they are aligned in realizing organizational goals under certain internal structural conditions. Our study also shares affinities with research on channels of internal influence in organizations, including stakeholder receptivity (McDonnell et al. 2015), middle manager involvement (Huy 2002), and executive ideology (Briscoe et al. 2014). Studies like these tend not to be framed in terms of "internal buffering." We believe that, going forward, our elaboration of the concept of "internal buffering" will provide a useful framework for analyzing how external institutional pressures are translated internally to influence organizations.

Third, we directly theorize and test the association between efficiency imperatives and coupling of legitimacy structures and practices. While the specter of efficiency demands looms large in decoupling studies, they are not typically the object of empirical study. The literature broadly assumes that the implementation of legitimacy structures will be impeded by efficiencyrelated imperatives emanating from the organizational environment. However, to understand the coupling and decoupling of legitimacy structures, it is critical to recognize that environmental efficiency imperatives get operationalized as formal organizational structures and to investigate how these structures are related both to organizational practices and to other organizational structures. Our investigation shows that while some efficiency structures buffer the internal impact of legitimacy structures, this can be mitigated by certain managerial structures. These findings extend understandings about the relationship between legitimacy and efficiency imperatives that lie at the core of the decoupling literature.

Last, we extend the literature on certification to management systems standards. Our supplementary analysis reveals heterogeneity among certification systems, highlighting the importance of continuous process improvement and input from multiple units in designing management systems. We found no statistically significant labor practice improvement among suppliers certified to prescriptive management system standards, which impose a static set of objectives. Such certifications are often used as a "seal of approval" to market good practices to reputation-sensitive global buyers, though we find no evidence that adopters are particularly adept at substantially improving those practices. Instead, our finding that certification is associated with greater improvement turns out to be driven entirely by generative management systems, which emphasize continuous improvement processes and input from multiple units via self-assessment activities, without prescribing specific substantive outcomes. These findings contribute to the handful of studies that have investigated whether certification to management systems standards in one domain - such as environmental compliance or quality control-can improve management practices in ways that spill over into other domains (King et al. 2005, Levine and Toffel 2010, Lim and Prakash 2017). And they suggest the need for caution in assessing the value of certification and more nuanced attention to the design features of different management certification systems when theorizing and testing their effects.

\section{Contribution to the Literature on Labor Practices in Global Supply Chains}

Studies examining labor practices in global supply chains have focused on external institutional determinants of compliance with privately imposed labor codes of conduct, including civil society institutions (Seidman 2007, Vogel 2008, Anner 2012, Anner et al. 2013, Distelhorst et al. 2015, Toffel et al. 2015, Bartley and Egels-Zandén 2016, James et al. 2018), state-based institutions like the 
stringency of domestic labor law (Locke et al. 2013, Distelhorst et al. 2015, Toffel et al. 2015), and government inspection practices (Amengual 2010, Amengual and Chirot 2016). Our study extends this literature by empirically investigating the internal organizational structures that might impede or expedite suppliers' compliance with labor codes.

We also provide important new empirical evidence in the debate over the relationship of management systems and unions. Some studies suggest that the two are complementary (e.g., Bartley 2005, Rodriguez-Garavito 2005), others that certified management systems are used as a substitute for unions (e.g., Esbenshade 2004, Anner et al. 2013). Our findings provide evidence that the relationship between these two structures is complementary in suppliers that have adopted both: each enhances the positive association of the other with the coupling of codes of conduct and labor practices. However, complementarity might depend on suppliers' willingness to engage in the kind of cross-organization dialogue we theorize to cultivate and utilize information provided by workers about workplace conditions. Studies rejecting the complementarity of these two structures tend to be in contexts where suppliers used certification strategically to crowd out unions (e.g., Esbenshade 2004, Anner et al. 2013). We suspect that these structures may very well lack complementarity if they are not implemented synergistically to increase cross-organization dialogue, but future research is needed to identify the precise mechanisms driving complementarity. This suggests the need for caution in assessing the value of certification and for nuance in understanding the design and function of different management certification systems when theorizing and testing their effects.

Our examination of high-powered productivity incentives contributes to the literature that examines the relationship between labor standards and global value chain incentive structures. Many have argued that supplier labor standards are largely shaped by the incentives created by buyer sourcing practices (e.g., Bartley 2005, Locke 2013). Others have examined how the internal incentives created by "lean production systems" shape working conditions. Lean production emphasizes waste minimization and work flow maximization to increase productivity. Like the high-powered productivity incentives we study, lean production systems have been criticized for their association with intensified workloads and deteriorated working conditions (e.g., Landsbergis et al. 1999, Parker 2003, Stewart et al. 2009). Yet, recent studies show either mixed relationships (e.g., Jackson and Mullarkey 2000, Hasle 2009) or positive relationships (e.g., Locke and Romis 2007, 2010; Distelhorst et al. 2016) between lean production and working conditions. We extend this literature by exploring the relationship between labor standards improvement and a different type of productivity incentive-piece-rate payment, and by showing how this relationship is conditioned by other organizational structures. Our data only allow us to investigate one type of productivity incentive, and we encourage future studies to examine the relationship between labor standards improvement and the many different types of production incentive systems suppliers have instituted.

Finally, our findings provide important insights for MNCs selecting suppliers and designing governance regimes to improve labor practices. Many MNCs have focused on long-term relationships with suppliers and helping them improve their labor practices. Our findings suggest that MNCs can strategically target suppliers having managerial structures like generative certifications and worker participation, while being wary of suppliers using piece-rate systems. Furthermore, because of the influence of economic incentives on labor practices, altering the internal payment structure from piece-rate to hourly may help. For suppliers that cannot change their payment schemes systemically in the near term, instituting alternative governance structures, including worker participation and certification programs, might reduce the negative influence of high-powered productivity incentives.

\section{Limitations and Future Directions}

There are several limitations in our study. First, we do not observe why the suppliers in our sample adopted various efficiency and managerial structures; for instance, whether doing so was voluntary or coerced (and if so, by whom) and whether structures were adopted symbolically with the intent to decouple them from practices. We focus on postadoption outcomes rather than the conditions and motivations surrounding adoption. We acknowledge that adopters and nonadopters might differ in many unobservable aspects, such as management attitudes and organizational capacity. Becoming certified or unionized at different times or under different conditions may also influence the improvement of labor practices differently. Our data set does not enable us to empirically disentangle these differences, which remain important opportunities for future research.

Second, our data set lacks data on supplier profitability and many management characteristics-including the use of productivity-enhancing structures other than piece-rate payment-and on buyer-supplier order history and contractual terms, all of which might influence suppliers' improvement rates. We encourage future research to consider the possible relationship between different business models and improvement in labor practices. In addition, we rely on existing literature to hypothesize rather than directly observing the intraorganizational processes in suppliers. While the structures we hypothesize are designed to promote intraorganizational dialogue, we cannot observe the extent to which 
they do. Additional qualitative research is required to answer these important questions.

Lastly, ours is one of many papers that use audit scores as a measure of compliance with labor codes of conduct (e.g., Locke et al. 2007, Oka 2010, Ang et al. 2012, Distelhorst et al. 2015, Toffel et al. 2015), but researchers and other stakeholders should be aware of the limitations of audit reports for measuring improvements in labor conditions. The improvement of audit scores reflects changes in compliance as judged by auditors, and auditor judgment is based on their review of documented evidence (e.g., payroll records) as well as their ability to interview workers and observe actual conditions, which supplier management can seek to impede.

\section{Conclusion}

Many skeptics have argued that organizational legitimacy structures are not associated with actual changes in organizational practices. Our findings suggest that the coupling of legitimacy structures and organizational practices is conditioned by the organization's internal structural conditions, particularly the extent to which the core organizational efficiency imperatives are buffered from change or made more permeable to change by other organizational structures. Our study suggests the need to look beyond the symbolism of organizational legitimacy structures and attend to how they can be associated with actual implementation and improvement.

\section{Acknowledgments}

For insightful comments on drafts of this article, the authors thank participants at the Boston Area Global Labor Standards Meeting at MIT Sloan School of Management and the Social Innovation and Change Workshop at Harvard University. They gratefully acknowledge the research assistance of Melissa Ouellet.

\footnotetext{
Endnotes

${ }^{1}$ International Organization for Standardization, https://www.iso .org/management-system-standards.html.

${ }^{2}$ As described below, robustness tests that account for variation in this time lag between successive audits yield the same inferences as our primary results.

${ }^{3}$ We use suppliers and factories interchangeably, both referring to the establishment audited. All supplier/factory-level variables are measured at the establishment level. In addition, while it is possible that some of the thousands of audited establishments in our data set might be owned by a firm that operates multiple supplier factories, these establishments are not owned by the buyers, which tend to be brands. Our social auditing data does not include establishment names or ownership information.

${ }^{4}$ As explained below, we also estimate supplier fixed-effects models based on the full sample that includes suppliers whose piece-rate payment, certification, or union status changes, which generate results largely consistent with our primary results.

${ }^{5}$ Note that 8,323 is less than twice the number of focal audits because some suppliers were audited more than twice in our sample period, which results in 1,451 audits serving both as a focal audit in one observation and as a prior audit in another observation.
}

${ }^{6}$ The terms of our data-sharing agreement require us to protect the identity of the social audit firm that provided the data to us, which prevents us from disclosing the full list of audit categories and how they are aggregated and weighted to produce the final score of labor practice.

${ }^{7}$ Our model that predicts improvement (that is, Score $_{i, t}-$ Score $_{i, t-1}$ ) while controlling for the prior audit score $\left(\right.$ Score $\left._{i, t-1}\right)$ is virtually mathematically identical to a model that predicts the focal audit score $\left(\right.$ Score $\left._{i, t}\right)$ while controlling for the prior audit score $\left(\right.$ Score $\left._{i, t-1}\right)$. That is, our current approach can be expressed as $\left(\right.$ Score $_{i, t}-$ Score $\left._{i, t-1}\right)=\beta_{1}$ Score $_{i, t-1}+\beta_{2} X_{i, t}+$ $\varepsilon_{i, t}$. Adding Score $_{t-1}$ to both sides yields Score $_{i, t}=\left(\beta_{1}+1\right)$ Score $_{i, t-1}+$ $\beta_{2} X_{i, t}+\varepsilon_{i, t}$. Note that these alternative specifications yield identical coefficients on our hypothesized variables $\left(\beta_{2}\right)$.

${ }^{8}$ If some factories in our sample do not use piece-rate pay but instead supplement their hourly wage scheme with other productivity incentives, such as production bonuses, that we do not observe in our data, our estimated coefficient on piece-rate payment should be considered the lower bound of the true impact of high-powered incentives. This is because our estimates identify the difference between factories that rely on piece-rate payment and all other factories and some of those other factories might rely on other high-powered incentives.

${ }^{9}$ For the full list of management system standards, see Table D1 of Online Appendix D.

${ }^{10}$ Nearly $15 \%$ of the establishments in our sample are certified to at least one management standard, which is broadly similar to certification rates among manufacturing establishments in China and in the United States, according to our calculations based on data from Bloomberg Terminal, the International Organization for Standardization's 2016 ISO Survey, and the US Census Bureau's Statistics of U.S. Businesses. Because certified suppliers might be especially good at keeping records, creating systems for managing problems, and documenting changes-which could trigger improved audit scores-we explored whether certification was associated with improvements in the subset of audited labor practice items that are based on physically examining shop floor conditions (rather than process and system related issues that might be associated with better record keeping). Examples of such items include the functioning of machines' emergency stop switches, the installation of fire hoses, the proper use of personal protective equipment, and the correct labeling of chemicals and materials. Like our main results, we find that certified suppliers exhibit more improvement in labor practice audit items that are based on examining shop floor conditions $(\beta=0.810, p<0.01)$. This allays the concern that our main certification result is driven solely by certified establishments being especially good at process and system issues like recordkeeping. As an aside, the coefficients on piece rate payment and workers' union are quite similar in magnitude and statistical significance across these two models, which indicates that those structures are associated with comparable degrees of improvement in both documented and examined items of labor practices.

${ }^{11}$ Audit team demographics not only might influence auditor scrutiny and thus audit score (Short et al. 2016), but also might cause different amounts of knowledge transfer to be conveyed to and/or received by the audited establishment (e.g., auditors could teach suppliers how to remediate issues), which could influence the learning and improvement that would be reflected in the next audit score and thus in our improvement measure. We theorize neither the net magnitude of these interconnected relationships nor their potential influence on improvement; we merely control for them, so as not to risk omitted variable bias that could contaminate the estimates of our hypothesized effects.

${ }^{12}$ Because three control variables (paid by buyer, audit team average age, and audit team maximum tenure) have moderately high correlations between values measured at the focal and the prior audit, we investigated whether our inclusion of them measured at time $t$ and time $\mathrm{t}-1$ (that is, these variables being measured at the focal audit and the 
prior audit) influence the coefficients on our hypothesized variables. We compared our primary model's estimates to two alternative models: a model that omitted these three variables measured at time $t$ (the focal audit), and a model that instead omitted these three variables measured at time $\mathrm{t}-1$ (the prior audit). Both of these alternative models yielded coefficients on our hypothesized variables that remained statistically significant and of very similar magnitude to our primary results (differences ranged from $0.3 \%$ to $4.4 \%$ ).

${ }^{13}$ For instance, the correlation of supplier's size between the prior and focal audits is 0.96 and the correlation of female worker ratio between the prior and focal audits is 0.86 .

${ }^{14}$ As a robustness test, we include three supplier-country-level variables rule of law, press freedom, and FDI inflows, which yielded nearly identical results. Because our main models use suppliercountry fixed effects, including these supplier-country-level variables risks multicollinearity issues. We thus do not include them in the main models.

${ }^{15}$ A likelihood-ratio test indicates that our main model (Column 1) provides significantly more explanatory power than a model that omits our three independent variables (certification, workers' union, and piece-rate payment $)\left(\chi^{2}=39.2 ; \mathrm{p}<0.01\right)$, and a Wald test assessing whether the three independent variables in our main model are jointly zero is strongly rejected $(\mathrm{F}=48.6 ; \mathrm{p}<0.01)$.

${ }^{16}$ Noting that audit team maximum tenure (prior audit) and audit team average age (prior audit) are highly correlated $(\rho=0.55)$, and audit team maximum tenure (focal audit) and audit team average age (focal audit) are highly correlated $(\rho=0.59)$, we reestimated our main model (Column 1 of Table 2) except omitting prior and focal audit team maximum tenure, and then, separately, omitting the audit team average age variables corresponding to the prior and focal audit. This reduced the magnitude of the significant negative coefficient on audit team maximum tenure (focal audit) and the magnitude of the significant positive coefficient on audit team maximum tenure (prior audit) and led to the coefficients on both audit team average age (focal audit) and audit team average age (prior audit) becoming nearly 0 and nonsignificant. This indicates that significant coefficient reported in Table 2 on audit team average age (focal audit) is driven by multicollinearity and should be interpreted with caution. The coefficients on our hypothesized variables were nearly identical across these alternative specifications.

${ }^{17}$ Specifically, we find positive significant coefficients on audit team maximum tenure (prior audit) and mixed-gender team (prior audit) and a Wald test statistic indicating that the negative coefficient on allfemale team (prior audit) differs significantly from the coefficient on mixed-gender team (prior audit) $(F=11.2, \mathrm{p}<0.01)$.

${ }^{18}$ Specifically, we reestimated our main model (Column 1 of Table 2) except that we omitted paid by buyer (focal audit), and then, separately, omitted paid by buyer (prior audit). This increased the magnitude of the significant positive coefficient on paid by buyer (prior audit), and rendered the coefficient on paid by buyer (prior audit) significant. Coefficients on our hypothesized variables were nearly identical across these alternative specifications.

\section{References}

AFL-CIO (2013) Responsibility outsourced: Social audits, workplace certification and twenty years of failure to protect worker rights. Accessed July 18, 2018, https://www.ituc-csi.org/responsibility -outsourced-social.

Amengual M (2010) Complementary labor regulation: The uncoordinated combination of state and private regulators in the Dominican Republic. World Development 38(3):405-414.

Amengual M, Chirot L (2016) Reinforcing the state: Transnational and state labor regulation in Indonesia. Indust. Labor Relations Rev. 69(5):1056-1080.
Ang D, Brown D, Dehejia R, Robertson R (2012) Public disclosure, reputation sensitivity, and labor law compliance: Evidence from Better Factories Cambodia. Rev. Development Econom. 16(4):594-607.

Anner M (2012) Corporate social responsibility and freedom of association rights: The precarious quest for legitimacy and control in global supply chains. Politics Soc. 40(4):609-644.

Anner M, Liu X (2016) Harmonious unions and rebellious workers: A study of wildcat strikes in Vietnam. ILR Rev. 69(1):3-28.

Anner M, Bair J, Blasi J (2013) Toward joint liability in global supply chains: Addressing the root causes of labor violations in international subcontracting networks. Comparative Labor Law Policy J. 35(1):1-43.

Appelbaum E (2000) Manufacturing Advantage: Why High-Performance Work Systems Pay Off (Cornell University Press, Ithaca, NY).

Bader C (2015) Whose job is it to prevent worker abuse abroad? The Atlantic (May 18), https://www.theatlantic.com/business/ archive/2015/05/the-importance-of-supply-chain/393320.

Bartley T (2005) Corporate accountability and the privatization of labor standards: Struggles over codes of conduct in the apparel industry. Res. Political Sociol. 14:211-244.

Bartley T (2011) Certification as a mode of social regulation. Levi-Faur D, ed. Handbook on the Politics of Regulation (Edward Elgar, Cheltenham, UK), 441-452.

Bartley T, Child C (2014) Shaming the corporation: The social production of targets and the anti-sweatshop movement. Amer. Sociol. Rev. 79(4):653-679.

Bartley T, Egels-Zandén N (2016) Beyond decoupling: Unions and the leveraging of corporate social responsibility in Indonesia. SocioEconom. Rev. 14(2):231-255.

Bender KA, Sloane PJ (1999) Trade union membership, tenure and the level of job insecurity. Appl. Econom. 31(1):123-135.

Berliner D, Prakash A (2015) "Bluewashing" the firm? Voluntary regulations, program design, and member compliance with the United Nations Global Compact. Policy Stud. J. 43(1):115-138.

Besharov ML, Smith WK (2014) Multiple institutional logics in organizations: Explaining their varied nature and implications. Acad. Management Rev. 39(3):364-381.

Binder A (2007) For love and money: Organizations' creative responses to multiple environmental logics. Theory Soc. 36(6): 547-571.

Boiral O (2007) Corporate greening through ISO 14001: A rational myth? Organ. Sci. 18(1):127-146.

Briscoe F, Chin MK, Hambrick DC (2014) CEO ideology as an element of the corporate opportunity structure for social activists. Acad. Management J. 57(6):1786-1809.

Bromley P, Powell WW (2012) From smoke and mirrors to walking the talk: Decoupling in the contemporary world. Acad. Management Ann. 6(1):483-530.

Brown GD, O'Rourke D (2007) Lean manufacturing comes to China: A case study of its impact on workplace health and safety. Internat. J. Occupational Environ. Health 13(3):249-257.

Caraway TL (2007) Assembling Women: The Feminization of Global Manufacturing (ILR Press, Ithaca, NY).

Chen M-s, Chan A (2004) Employee and union inputs into occupational health and safety measures in Chinese factories. Soc. Sci. Medicine 58(7):1231-1245.

Collins D (1997) The ethical superiority and inevitability of participatory management as an organizational system. Organ. Sci. 8(5):489-507.

Distelhorst G, Hainmueller J, Locke RM (2016) Does lean improve labor standards? Management and social performance in the Nike supply chain. Management Sci. 63(3):707-728.

Distelhorst G, Locke RM, Pal T, Samel H (2015) Production goes global, compliance stays local: Private regulation in the global electronics industry. Regulation Governance 9(3): 224-242. 
Dobbin F, Kelly EL (2007) How to stop harassment: Professional construction of legal compliance in organizations. Amer. J. Sociol. 112(4):1203-1243.

Dobbin F, Sutton JR (1998) The strength of a weak state: The rights revolution and the rise of human resources management divisions. Amer. J. Sociol. 104(2):441-476.

Dohmen T, Falk A (2011) Performance pay and multidimensional sorting: Productivity, preferences, and gender. Amer. Econom. Rev. 101(2):556-590.

Dong X, Entzel P, Men Y, Chowdhury R, Schneider S (2004) Effects of safety and health training on work-related injury among construction laborers. J. Occupational Environ. Medicine 46(12): 1222-1228.

Drucker PF (1974) Management Tasks, Responsibilities, Practices (Harper \& Row, New York).

Dunlop JT, Weil D (1996) Diffusion and performance of modular production in the U.S. apparel industry. Indust. Relations J. Econom. Soc. 35(3):334-355.

Edelman LB (1992) Legal ambiguity and symbolic structures: Organizational mediation of civil rights law. Amer. J. Sociol. 97(6):1531-1576.

Elias J (2005) The gendered political economy of control and resistance on the shop floor of the multinational firm: A case-study from Malaysia. New Political Econom. 10(2):203-222.

Esbenshade J (2004) Codes of conduct: Challenges and opportunities for workers' rights. Soc. Justice 31(3):40-59.

Fiss PC, Zajac EJ (2004) The diffusion of ideas over contested terrain: The (non)adoption of a shareholder value orientation among German firms. Admin. Sci. Quart. 49(4):501-534.

Flanagan RJ (2006) Globalization and Labor Conditions: Working Conditions and Worker Rights in a Global Economy (Oxford University Press, Oxford, UK).

Freeman RB (1980) The exit-voice tradeoff in the labor market: Unionism, job tenure, quits, and separations. Quart. J. Econom. 94(4):643-673.

Friedman E, Lee CK (2010) Remaking the world of Chinese labour: A 30-year retrospective. British J. Indust. Relations 48(3):507-533.

Gereffi G (2005) The global economy: organization, governance, and development. Handbook Econom. Sociol. 2:160-182.

Gereffi G, Christian M (2009) The impacts of Wal-Mart: The rise and consequences of the world's dominant retailer. Annual Rev. Sociol. 35(1):573-591.

Gillen M, Baltz D, Gassel M, Kirsch L, Vaccaro D (2002) Perceived safety climate, job demands, and coworker support among union and nonunion injured construction workers. J. Safety Res. 33(1):33-51.

Gould D (2005) The problem with supplier audits. Corporate Responsibility Management 2(1):24-29.

Hafner-Burton EM, Tsutsui K (2005) Human rights in a globalizing world: The paradox of empty promises. Amer. J. Sociol. 110(5):1373-1411.

Hallett T (2010) The myth incarnate recoupling processes, turmoil, and inhabited institutions in an urban elementary school. Amer. Sociol. Rev. 75(1):52-74.

Hasle P (2009) Lean and the psychosocial work environment. Saksvik PO, ed. Prerequisites for Healthy Organizational Change (Bentham Science Publishers, Oak Park, IL), 1-9.

Holmstrom B, Milgrom P (1991) Multitask principal-agent analyses: Incentive contracts, asset ownership, and job design. J. Law Econom. Organ. 7(Special Issue):24-52.

Holweg M (2007) The genealogy of lean production. J. Oper. Management 25(2):420-437.

Hugill A, Short JL, Toffel MW (2018) Beyond symbolic responses to private politics: Examining labor standards improvement in global supply chains. Working Paper 17-001, Harvard Business School, Boston.

Huy QN (2002) Emotional balancing of organizational continuity and radical change: The contribution of middle managers. Admin. Sci. Quart. 47(1):31-69.
International Organization for Standardization (2000) ISO 9001 Quality Management Systems Requirements (American National Standards Institute, Washington, DC).

Jackson PR, Mullarkey S (2000) Lean production teams and health in garment manufacture. J. Occupational Health Psych. 5(2):231-245.

James P, Miles L, Croucher R, Houssart M (2018) Regulating factory safety in the Bangladeshi garment industry. Regulation Governance, ePub ahead of print January 4, https://doi.org/10.1111/ rego.12183.

King AA, Lenox MJ, Terlaak A (2005) The strategic use of decentralized institutions: Exploring certification with the ISO 14001 management standard. Acad. Management J. 48(6):1091-1106.

Lamin A, Zaheer S (2012) Wall Street vs. Main Street: Firm strategies for defending legitimacy and their impact on different stakeholders. Organ. Sci. 23(1):47-66.

Landsbergis PA, Cahill J, Schnall P (1999) The impact of lean production and related new systems of work organization on worker health. J. Occupational Health Psych. 4(2):108-130.

Lazear EP (2000) The power of incentives. Amer. Econom. Rev. 90(2): 410-414.

LeBaron G, Lister J (2015) Benchmarking global supply chains: The power of the 'ethical audit' regime. Rev. Internat. Stud. 41(5):905-924.

Levine DI, Toffel MW (2010) Quality management and job quality: How the ISO 9001 standard for quality management systems affects employees and employers. Management Sci. 56(6):978-996.

Lilley R, Feyer AM, Kirk P, Gander P (2002) A survey of forest workers in New Zealand: Do hours of work, rest, and recovery play a role in accidents and injury? J. Safety Res. 33(1):53-71.

Lim A, Tsutsui K (2012) Globalization and commitment in corporate social responsibility: Cross-national analyses of institutional and political-economy effects. Amer. Sociol. Rev. 77(1):69-98.

Lim S, Prakash A (2017) From quality control to labor protection: ISO 9001 and workplace safety, 1993-2012. Global Policy 8(S3):66-77.

Lo CKY, Pagell M, Fan D, Wiengarten F, Yeung ACL (2014) OHSAS 18001 certification and operating performance: The role of complexity and coupling. J. Oper. Management 32(5):268-280.

Locke R, Romis M (2007) Improving work conditions in a global supply chain. MIT Sloan Management Rev. (January 1), https://sloanreview .mit.edu/article/improving-work-conditions-in-a-global-supply -chain.

Locke R, Amengual M, Mangla A (2009) Virtue out of necessity? Compliance, commitment, and the improvement of labor conditions in global supply chains. Politics Soc. 37(3):319-351.

Locke RM (2013) The Promise and Limits of Private Power: Promoting Labor Standards in a Global Economy (Cambridge University Press, Cambridge, UK).

Locke RM, Romis M (2010) The promise and perils of private voluntary regulation: Labor standards and work organization in two Mexican garment factories. Rev. Internat. Political Econom. 17(1):45-74.

Locke RM, Qin F, Brause A (2007) Does monitoring improve labor standards? Lessons from Nike. ILR Rev. 61(1):3-31.

Locke RM, Rissing BA, Pal T (2013) Complements or substitutes? Private codes, state regulation and the enforcement of labour standards in global supply chains. British J. Indust. Relations 51(3): 519-552.

McDonnell MH, King BG, Soule SA (2015) A dynamic process model of private politics: Activist targeting and corporate receptivity to social challenges. Amer. Sociol. Rev. 80(3):654-678.

Meng R, Smith D (1993) Union impacts on the receipt of workers compensation benefits. Indust. Relations 48(3):503-518.

Meyer JW, Rowan B (1977) Institutionalized organizations: Formal structure as myth and ceremony. Amer. J. Sociol. 83(2):340-363.

Morantz A (2009) The elusive union safety effect: Toward a new empirical research agenda. Eaton AE, ed. Proc. 61st Annual Meeting Labor and Employment Relations Assoc., San Francisco, 130-146.

Morse T, Punnett L, Warren N, Dillon C, Warren A (2003) The relationship of unions to prevalence and claim filing for work-related 
upper-extremity musculoskeletal disorders. Amer. J. Indust. Medicine 44(1):83-93.

Nadvi K, LunD-Thomsen P, Xue H, Khara N (2011) Playing against China: Global value chains and labour standards in the international sports goods industry. Global Networks 11(3):334-354.

Nissen B, Angee A, Weinstein M (2008) Immigrant construction workers and health and safety: The South Florida experience. Labor Stud. J. 33(1):48-62.

Nolan J (2014) Refining the rules of the game: The corporate responsibility to respect human rights. Utrecht J. Internat. Eur. Law 30(78):7-23.

Oka C (2010) Channels of buyer influence and labor standard compliance: The case of Cambodia's garment sector. Adv. Indust. Labor Relations 17:153-183.

Okhmatovskiy I, David RJ (2011) Setting your own standards: Internal corporate governance codes as a response to institutional pressure. Organ. Sci. 23(1):155-176.

O'Rourke D (2003) Outsourcing regulation: Analyzing nongovernmental systems of labor standards and monitoring. Policy Stud. J. 31(1):1-29.

Overdevest C (2010) Comparing forest certification schemes: The case of ratcheting standards in the forest sector. Socio-Econom. Rev. $8(1): 47-76$.

Parker SK (2003) Longitudinal effects of lean production on employee outcomes and the mediating role of work characteristics. J. Appl. Psych. 88(4):620-634.

Patterson PB (2007) Attributions of danger and responses to risk among logging contractors in British Columbia's Southern interior: Implications for accident prevention in the forest industry. Res. Econom. Anthropology 26:103-125.

Pfeffer J, Salancik GR (1978) The External Control of Organizations: A Resource Dependence Perspective (Harper \& Row, New York).

Prendergast C (1999) The provision of incentives in firms. J. Econom. Lit. 37(1):7-63.

Reilly B, Paci P, Holl P (1995) Unions, safety committees and workplace injuries. British J. Indust. Relations 33(2):275-288.

Rock M (2003) Labour conditions in the export-oriented garment industry in Bangladesh. South Asia J. South Asian Stud. 26(3):391-407.

Rodríguez-Garavito CA (2005) Global governance and labor rights: Codes of conduct and anti-sweatshop struggles in global apparel factories in Mexico and Guatemala. Politics Soc. 33(2):203-333.

Seidman G (2007) Beyond the Boycott: Labor Rights, Human Rights, and Transnational Activism (Russell Sage Foundation, New York).

Shea A, Nakayama M, Heymann J (2010) Improving labour standards in clothing factories: Lessons from stakeholder views and monitoring results in Cambodia. Global Soc. Policy 10(1):85-110.

Short JL, Toffel MW (2010) Making self-regulation more than merely symbolic: The critical role of the legal environment. Admin. Sci. Quart. 55(3):361-369.

Short JL, Toffel MW, Hugill AR (2016) Monitoring global supply chains. Strategic Management J. 37(9):1878-1897.

Social Accountability International (2016) Guidance document for social accountability 8000. Accessed December 5, 2018, http:// www.iqnet-certification.com/userfiles/SA8000_MS_New/18.\% 20SA8000\%202014\%20Guidance\%20Document_May\%202016 _FINAL.pdf.

Starmanns M (2017) Purchasing practices and low wages in global supply chains: Empirical cases from the garment industry. Conditions of Work and Employment Series 86, Working Paper 22268944, International Labour Office, Geneva.

Stewart P, Richardson M, Danford A, Murphy K (2009) "We Sell Our Time No More": Workers' Struggles Against Lean Production in the British Car Industry (Pluto Press, London).

Surroca J, Tribó JA, Zahra SA (2013) Stakeholder pressure on MNEs and the transfer of socially irresponsible practices to subsidiaries. Acad. Management J. 56(2):549-572.
Sutton JR, Dobbin F (1996) The two faces of governance: Responses to legal uncertainty in U.S. firms, 1955 to 1985 . Amer. Sociol. Rev. 61(5):794-811.

Target (2018) Labor \& human rights policies. Retrieved March 9, 2018, http://corporate.target.com/corporate-responsibility/responsible -sourcing/social-compliance/labor-and-human-rights.

Thompson JD (1967) Organizations in Action: Social Science Bases of Administrative Theory (McGraw-Hill, New York).

Thornton PH, Ocasio W, Lounsbury M (2012) The Institutional Logics Perspective: A New Approach to Culture, Structure, and Process (Oxford University Press, Oxford, UK).

Tilcsik A (2010) From ritual to reality: Demography, ideology, and decoupling in a post-communist government agency. Acad. Management J. 53(6):1474-1498.

Toffel MW, Short JL, Ouellet M (2015) Codes in context: How states, markets, and civil society shape adherence to global labor standards. Regulation Governance 9(3):205-223.

Utting P (2005) Corporate responsibility and the movement of business. Development Practice 15(3-4):375-388.

Vinodkumar MN, Bhasi M (2011) A study on the impact of management system certification on safety management. Safety Sci. 49(3):498-507.

Vogel D (2008) Private global business regulation. Annual Rev. Political Sci. 11(1):261-282.

Wagner JA (1994) Participation's effects on performance and satisfaction: A reconsideration of research evidence. Acad. Management Rev. 19(2):312-330.

Walters D (2006) One step forward, two steps back: Worker representation and health and safety in the United Kingdom. Internat. J. Health Services 36(1):87-111.

Westphal JD, Zajac EJ (2001) Decoupling policy from practice: The case of stock repurchase programs. Admin. Sci. Quart. 46(2): 202-228.

Williamson OE (1985) The Economic Institutions of Capitalism: Firms, Markets, Relational Contracting (Free Press, New York).

Yu X (2009) From passive beneficiary to active stakeholder: Workers' participation in CSR movement against labor abuses. J. Bus. Ethics 87(1):233.

Zajac EJ, Westphal JD (2004) The social construction of market value: Institutionalization and learning perspectives on stock market reactions. Amer. Sociol. Rev. 69(3):433-457.

Zajak S (2017) Transnational Activism, Global Labor Governance, and China (Palgrave Macmillan, New York).

Yanhua Bird is a PhD student in the organizational behavior program jointly offered by the Harvard Business School and the Department of Sociology at Harvard. Her research seeks to understand how different market regulation and governance institutions are developed and deployed, and their consequences on market participants.

Jodi L. Short is the Honorable Roger J. Traynor Professor of Law at UC Hastings College of the Law. She received her JD from Georgetown University Law Center and her PhD in sociology from the University of California, Berkeley. Her research is on the regulation of business, in particular the intersection of public and private regulatory regimes and the theory and practice of regulatory reform.

Michael W. Toffel is the Senator John Heinz Professor of Environmental Management and faculty chair of the business and environment initiative at the Harvard Business School. He received his $\mathrm{PhD}$ from the University of California, Berkeley. His research examines how companies and regulators manage environmental issues and working conditions in operations and supply chains. 